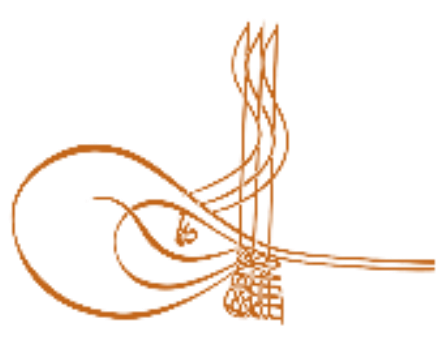

www.turkishstudies.net/social
Turkish Studies - Social Sciences

eISSN: $2667-5617$

Research Article / Araștırma Makalesi

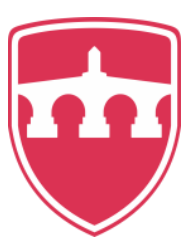

INTERNATIONAL

BALKAN

UNIVERSITY

Sponsored by IBU

\title{
8. Sınıf Türkçe Ders Kitabındaki (MEB, 2017) Cümle Bilgisi Etkinliklerine Eleştirel Bir Bakış
}

A Critical Point Of View Aiming At Sentence Knowledge Activities In 8th Grade Turkish Text Book (2017, MEB Press)

\author{
Gülşah Durmuş
}

\begin{abstract}
The aim of this study is to determine the sentence information activities for the process of reading and listening/ monitoring texts in six themes in Primary Turkish 8 Lessons (MEB, 2017a), Student Studybook (MEB, 2017b) and Teacher Guidebook (MEB, 2017c) interpret them and evaluate them with a critical perspective. In the study, scanning model, which is one of the descriptive research patterns, was used. In the books examined at the end of the study, it was determined that the activities shaped around the main and auxiliary elements of the sentence field, the main and auxiliary elements of the sentence such as sentence types according to meaning (positive, negative, question), place of predicate (canonical, transpose), type (noun and verb sentence) and structure (single predicate, multi predicate, verbial, conjunction); phrases (noun clauses, adjective clauses, verb and verb groups, etc.); idioms, proverbs and phrases that can be evaluated in a phrase or sentence structure; purpose according to its subject (active, passive) and object (transitive, intransitive), voice of verbs, sentence emphasis, sentence length, number of verbs in the sentence; meaning in sentence [(positive, negative, question, assumption, probability, comparison, suggestion, subjective and objective judgment; object- result, cause- effect sentences] and emotion (reproach, longing, sadness, regret, exaggeration, surprise, liking); expression disorders, etc. spread over a wide range in terms of the sentence information. At the end of the study, it was proposed to update and enrich the sentence information activities in 8th grade Turkish textbooks in the light of academic studies focused on grammar teaching processes, especially with the discovery learning in constructive approach carried out in the literature.
\end{abstract}

Structured Abstract: Aim of the Research: The aim of this study is to determine, interpret and critically evaluate sentence information activities for the process of reading and listening/ monitoring texts in six themes in 8th Grade Turkish Lesson (MEB, 2017a), Student Work (MEB, 2017b) and Teacher Guide Book (MEB, 2017c).

\section{Research Method}

Descriptive method, one of the qualitative research methods, was used in the research. "Descriptive studies were carried out to illuminate a given situation, make evaluations in line with standards and reveal

\footnotetext{
* Dr. Öğr. Üyesi, İstanbul Aydın Üniversitesi, Eğitim Fakültesi, Türkçe Öğretmenliği Programı Asst. Prof. Dr., İstanbul Aydin University, Education Faculty, Turkish Education Department ORCID 0000-0001-7469-3864

gulsahdurmus@aydin.edu.tr

Cite as/ Atıf: Durmuş, G. (2020). 8. Sınıf Türkçe ders kitabındaki (MEB, 2017) cümle bilgisi etkinliklerine eleştirel bir bakış, Turkish Studies - Social, 15(3), 1101-1126. https://dx.doi.org/10.29228/TurkishStudies.41500

Received/Geliş: 27 February/Şubat 2020

Checked by plagiarism software

Accepted/Kabul: 29 April/Nisan 2020

Published/Yayın: 30 April/Nisan 2020

Copyright $($ INTAC LTD, Turkey

CC BY-NC 4.0
} 
possible relationships between events" (Çepni, 2009). The study was carried out in the screening model (Büyüköztürk, 2010, p. 21), which is one of the descriptive research types. "Screening models are research approaches that aim to describe a situation that exists in the past or still as it exists. The event, individual or object that is the subject of the research was tried to be defined in its own conditions and as it is. No effort was made to change or influence them in any way. Th thing aimed to be known existis and it is there. The important thing is to be able to observe and determine it appropriately"(Karasar, 1994, p. 77).

\section{Examined Documents of the Research}

In the research, 8th grade Turkish Lesson (MEB, 2017a), Student Textbook (MEB, 2017b) and Teacher Guide Book (MEB, 2017c); were accepted as document and sentence information activities in these books were examined.

\section{Data Collection and Analysis}

During the data collection process, all the activities that were created for sentence information in the books accepted as documents were determined and recorded, and during the analysis of the data obtained, these activities were interpreted in the light of the data presented by the literature in the 2017 and 2019 Turkish Curriculum and sentence information. It was tried to be revealed that it can be evaluated within the context of sentence information. In this process, the issue of how these events can be updated in the light of current data in the literature was also mentioned, and in the conclusion part of the study, additions were made in the light of the data of the researchers who put forward their views on teaching grammar with a constructivist approach.

After all these explanations, determination and critical of sentence information activities which are formed for the processing processes of reading and listening/ monitoring texts in six themes in 8th Grade Turkish Lesson (2017a), Student Textbook (2017b) and Teacher Guidebook (2017c) The process of interpretation and evaluation with a view can be started. In this process, the gains and explanations that can be evaluated within the context of sentence information in 2017 and 2019 Turkish Curriculum were used as a guiding criterion. The books published in 2017 were examined in the study. This study, which can offer researchers the opportunity to make comparisons for a future study that will discuss the sentence information activities in the Turkish textbook, which was published recently and published on 28.05.2019, is important in this regard.

As stated by Güneş, constructivist approach is applied in language teaching in most countries in the world. In accordance with this approach, new grammar, skill and effectiveness approach, induction model and intuition method are used in grammar teaching. Grammar is not considered as a separate lesson but is considered to take place in language learning areas. With the intuition method, emphasis is placed not on memorizing the abstract rules of language, but on developing the language and mental skills of the student. It is aimed to learn the language rules by exploring them with various experimental activities such as scientific information. They are expected to learn the functions, rules and logic of the language and use them in reading and writing studies. In grammar teaching with intuition method, presentation is carried out in six stages. Observing the event, creating rules and hypotheses, practicing and transferring to the application (Güneş, 2013, p. 17).

At the stage of presentation, teacher examines grammatical events with students with various questions, makes and let students make spelling and corrections related to the event, discusses the problems of comprehension, enables students to understand the importance of grammar, and activates the prior knowledge of students about the grammar event discussed (Güneş, 2013, p. 180, 183 ).

At the stage of observing the event, teacher invites students to recognize the concept of grammar in the texts they read and to observe the events (Güneş, 2013, p. 180, 183).

In the step of changing samples and creating hypotheses, s/he asks students to classify according to their own criteria, observes and notes the processes they use, invites them to form hypotheses about the functions of the event, discusses the hypotheses with the students, teaches the necessary grammar changes according to the need (Güneş, 2013, p. 181, 183).

In the validation of hypothesis step, s/he invites students to use appropriate language changes to verify the applicability of their hypotheses in other texts (Güneş, 2013, p. 181, 183). 
In the rule-making step, students are asked to create precise rules and to examine and evaluate them in source grammar books (Güneş, 2013, p. 181, 183).

In the step of doing exercises, he plans activities and gives them these activities so that students learn new information (Güneş, 2013, pp. 182- 183).

In the step of transferring to application, he controls the event to improve what has been learned in the text writing process (Güneş, 2013, pp. 182- 183).

When all above mentioned steps are evaluated together, it can be observed that there is a wide variety in terms of subject scope that can be included in the sentence knowledge field of sentence information activities in the 8th Grade Turkish Course, Student Textbook and Teacher Guide Book (MEB; 2017a, 2017b, 2017c).

However it can be suggected that the boks to be prepared in the future should be updated and enriched by taking the opinions stated by Göğüş (1978), Sağır ve Demir Atalay (2016) ve Aslan (2017) and especially by the the discovery learning in constructive approach carried out in the literature, steps of which are explained in detail by Güneş (2013) and the six basic stages of grammer teaching process.

Keywords: Sentence Knowledge Activities, 8th Grade Turkish Lesson, Student Study and Teacher Guide Book; Grammar Teaching With The Discovery Learning Method In Constructive Approach.

Öz: Bu çalışmanın amacı, 8. Stnıf Türkçe Ders (MEB, 2017a), Öğrenci Çalı̧ma (MEB, 2017b) ve Öğretmen Kılavuz Kitabı'ndaki (MEB, 2017c) altı temada yer alan okuma ve dinleme/ izleme metinlerinin işleniş süreçlerine yönelik oluşturulmuş cümle bilgisi etkinliklerinin tespit edilmesi ve eleștirel bir bakışla yorumlanıp değerlendirilmesidir. Çalışmada betimsel araştırma desenlerinden tarama modeli kullanılmıştır. Çalışma sonunda incelenen kitaplarda cümlenin ana ve yardımcı ögeleri; anlamına (olumlu, olumsuz, soru), yükleminin yerine (kurallı, devrik), türüne (isim ve fiil cümlesi) ve yapısına (tek yüklemli, çok yüklemli, fiilimsi bulunan, bağlaç bulunan) göre cümle çeşitleri; sözcük grupları (isim tamlamaları, sıfat tamlamaları, fiilimsiler ve fiilimsi grupları vb.); birer sözcük grubu ya da cümle yapılanışında değerlendirilebilecek deyimler, atasözleri ve kalıp sözler; öznesine (etken, edilgen) ve nesnesine (geçişli, geçişsiz) göre fiil çatıları, cümle vurgusu, cümle uzunluğu, cümlede yüklem sayısı; cümlede anlam (olumlu, olumsuz, soru, varsayım, ihtimal, karşılaştırma, öneri, öznel ve nesnel yargı, amaç- sonuç, sebep- sonuç) ve duygu (sitem, özlem, üzülme, pişmanlık, abartma, şaşırma, beğenme); anlatım bozuklukları vb. konuları etrafında şekillenen etkinliklerin cümle bilgisi alanı açısından geniş bir yelpazeye yayıldığı tespit edilmiştir. Çalışma sonunda 8 . sınıf Türkçe ders kitaplarında yer alan cümle bilgisi etkinliklerinin alanyazında gerçekleștirilen yapılandırmacı yaklaşım ile özellikle de sezdirme yöntemiyle dil bilgisi öğretim süreçlerine odaklanılan akademik çalışmalar ışığında güncellenmesi ve zenginleştirilmesi teklif edilmiş̧ir.

Anahtar Kelimeler: Cümle Bilgisi Etkinlikleri, 8. Sınıf Türkçe Ders, Öğrenci Çalışma ve Öğretmen Kılavuz Kitabı; Sezdirme Yöntemiyle Dil Bilgisi Öğretimi.

\section{Giriş}

Gramer, insan kafasındaki düşünceyi söze ve söz bütününe dönüştüren dili, bilimsel ölçüler içinde anlatan, o dilin anlaşılması ve kullanılması için gerekli yöntem ve kuralları bir sistem yapısı içinde öğreten bilim dalıdır. Sözlük ve gramerler, dili kuşaklar arasında unutulmaktan kurtaran, onları birbirine bağlayan bağlardır. Gramer, aynı zamanda bir dilin sağlıklı olarak gelişmesinin de anahtarıdır. O dili konuşan toplumun kültür varlığının korunmasında ve sağlıklı bir biçimde yol alışında başlıca etkendir (Korkmaz, 2014, s. 86). Bir dilin seslerini, sözcük türlerini, bunların yapılarını, tümce olarak dizilmelerini ve tümce içindeki görevlerini, çekimleriyle ilgili kurallarını, inceleyen bir dil bilimi dalıdır. Dillerin genel olarak nasıl oluştuğunu, evrimlerini, dil olaylarını inceleyen bilim ise dil bilim adını alır. Her dilin kendine özgü kuralları bulunduğu için ayrı bir dil bilgisi vardır (Göğüş, 1978, s. 337). 
Bat1 Türkçesinin grameri üzerinde durduğu kitabı Türk Dil Bilgisi’nde Ergin, gramer tabirini geniş anlamda ele alarak dil bilgisi karşılığı olarak kullanmış ve terimin dar mânâsı ile dil bilgisinin fonetik ve sentaks kısımlarının dışında kalan konuları için kullanıldığına vurgu yapmıştır. Ergin'e göre bir dili bütün cepheleriyle inceleyen bilgi kolu olan dil bilgisinin dilin seslerini inceleyen kısmına ses bilgisi (fonetik), kelime ve şekillerin yapısını inceleyen kısmına şekil bilgisi (morfoloji), kelime ve şekillerin kökenini araştıran kısmına köken/ menşe bilgisi yahut türeme bilgisi (etimoloji), kelime ve şekillerin mânâları üzerinde duran kısmına mânâ bilgisi (semantik), kelime ve şekillerin birbirleriyle olan ilişkilerini ve cümleleri inceleyen kısmına ise cümle bilgisi (sentaks) adı verilir. Ancak bu bölümler arasına kesin sınırlar çizmek mümkün değildir çünkü her birinin diğerine karışan tarafları vardır. Özellikle şekil, köken ve anlam bilgilerini birbirinden ayırmaya imkân yoktur. Nitekim dil, seslerden en geniş cümlelere kadar bir bütündür ve onun bütün yönleriyle bir bütün olarak ele alınması gerekmektedir. Tıpkı dil gibi dil bilgisi de bir bütün hâlinde değerlendirilip öyle çözümlenmelidir. Dil bilgisinin vazifesi; seslerden cümleye kadar bütün dil birliklerini yapı, mânâ ve vazife bakımından incelemektir. Dil bilgisi çözümlemelerinde de klasik bölümlemelerden ziyade yapı, mânâ ve vazife ölçütlerinin esas alınması daha yerinde olacaktır (Ergin, 2013, s. 28).

Dil bilgisi, Latince "harf ve işaret" anlamındaki "gramma" kelimesi ile "harfleri yazma ve okuma sanatı" olarak açıklanan "grammatica" kelimesinden gelmektedir. Eskiden harf okumayazma sanatı olarak ele alınan dil bilgisi, günümüzde bir dilin ses, biçim, cümle ve metin yapısını inceleyen, anlam ve görevlerini ortaya koyan geniş bir alan olmuştur. Dil bilgisi, hem alt alanlarındaki gelişmeleri (fonetik, morfoloji, sentaks, semantik, etimoloji) hem de aralarındaki ilişkileri kapsamaktadır (Güneş, 2013, s. 172- 173).

Dil bilim, değişik diller üzerinde incelemeler yaparak dillerin ortak özelliklerinin ortaya konmasına yönelen bilim dalıdır. Buna bağlı olarak herhangi bir dilin işleyişini, kurallarını tespit etmeye çalışan dil bilgisi/ gramer çalışmaları da dil bilimden soyutlanamaz. Dil bilimin inceleme konuları içine giren dil olaylarından söz dizimi de böylece dil bilgisinin olduğu kadar dil bilimin de önemli bir dalını kapsamaktadır. Günümüzde geleneksel yaklaşımın yanı sıra yeni kuramlara göre de söz dizimi çalışmaları yapılmaktadır (Atabay, Özel, Çam; 1981, s. 11).

Bir dilde, kelimelerin, kelime gruplarının cümle ve söz içindeki görevlerini, birbirleriyle olan ilişkilerini, sıralanışlarını ve cümle türlerini inceleyen dil bilgisi dalına cümle bilgisi adı verilir (Korkmaz, 1992, s. 33). Cümleyi ve kelime gruplarını oluşturan kuralları, kelimelerin bir araya gelme koşullarını, kelimeler ve cümle ögeleri arasındaki ilişkiyi inceleyen dil bilgisi dalı; söz dizimidir (nahiv, sentaks) (Özmen, 2013, s. 3).

Gerçekler dünyasındaki varlık ve eylemlerin dildeki adlarından oluşan sözlükler, dilin nedensiz genellemelerden doğmuş sosyal yapısını; varlık ile varlık (söz öbekleri) ve varlık ile eylem (cümle) gibi başlıca iki türü olan söz dizimi ise dilin nedenli özellemelere dayalı bireysel yapısını ifade eder. Dilin söz varlığı yani sözlük, toplumun geçtiği yolların; söz dizimi ise kişinin geçtiği yolların toplamıdır (Karaağaç, 2009, s. 13).

Söz diziminin konusu, yargısız bir anlatım birimi olan kelime grupları ile yargılı bir anlatım birimi olan cümlenin yapısı, işleyişi, görevleri ve anlam özellikleridir. Cümlelerin bağlanma şekilleri ile bağlanan cümleler arasındaki şekil ve anlam ilişkileri de söz diziminin konusudur (Karahan, 2018, s. 9). Aslında cümle; bir fikri, bir düşünceyi, bir hareketi, bir duyguyu, bir hadiseyi tam olarak bir hüküm hâlinde ifade eden kelime grubudur. Kelime grupları, belirtme grupları iken cümle bir hüküm grubudur. Cümlenin temel fonksiyonu bir hüküm ifade etmektir. Onun için cümle; en tam, en geniş kelime grubudur (Ergin, 2013, s. 398). Cümle düzeyinde ele alınan anlatım bozuklukları da [eksiklik, fazlalık, sıra yanlışlı̆̆ı, uyumsuzluk vb. (Ercilasun, 2010, s. 294- 296)] cümle bilgisinin inceleme alanına dâhil edilmesi gereken konular olarak belirtilebilir.

Turkish Studies - Social, 15(3) 
2017 Türkçe Dersi Öğretim Programı'nda cümle bilgisi kapsamında ele alınabilecek kazanım ve açıklamalar, 8. sınıf düzeyinde yer almaktadır. Bu kazanım ve açıklamalarını şu şekilde sıralamak mümkündür: "T.8.3.5. Bağlamdan yararlanarak bilmediği kelime ve kelime gruplarının anlamını tahmin eder. a) Ögrencilerin tahmin ettikleri kelime ve kelime gruplarını ögrenmek için sözlük, atasözleri ve deyimler sözlüğ̈̈ vb. araçları kullanmaları sağlanır. b) Öğrencinin ögrrendiği kelime ve kelime gruplarından sözlük oluşturması teşvik edilir"; "T.8.3.6. Deyim, atasözü ve özdeyişlerin metne katkısını belirler"; "T.8.3.7. Metindeki söz sanatlarını tespit eder. Benzetme (teşbih), kişileştirme (teşhis), konuşturma (intak) ve karşıtllk(tezat), abartma (mübalağa) söz sanatlarının belirlenmesi sağlanır”; “T.8.3.8. Metindeki anlatım bozukluklarını belirler. Dil bilgisi yönünden anlatım bozuklukları üzerinde durulur"; "T.8.3.9. Fiilimsilerin cümledeki işlevlerini kavrar. Fiilimsilerin türleri fark ettirilir. Ekler ezberletilmez"; "T.8.3.10. Geçiş ve bağlantı ifadelerinin metnin anlamına olan katkısını değerlendirir. Oysaki, başka bir deyişle, özellikle, kisaca, böylece, ilk olarak ve son olarak ifadeleri üzerinde durulur"; "T.8.3.15. Metinle ilgili sorular sorar"; "T.8.3.21. Metnin içeriğini yorumlar. a) Yazarın olaylara bakış açısının tespit edilmesi sağlanır. b) Metindeki öznel ve nesnel yaklaşımların tespit edilmesi sağlanır. c) Metindeki örnek ve ayrıntılara atıf yapılması sağlanır"; "T.8.3.25. Okudukları ile ilgili çıkarımlarda bulunur. Neden-sonuç, amaç-sonuç, koşul, karşılaştırma, benzetme, örneklendirme, abartma, nesnel, öznel ve duygu belirten ifadeler üzerinde durulur"; "T.8.4.7. Yazılarını zenginleştirmek için atasözleri, deyimler ve özdeyişler kullanır"; "T.8.4.15. Yazılarında uygun geçiş ve bağlantı ifadelerini kullanır. Oysaki, başka bir deyişle, özellikle, ilk olarak ve son olarak ifadelerinin kullanılması sağlanır"; "T.8.4.16. Yazdıklarını düzenler. Dil bilgisine dayalı anlatım bozuklukları bakımından yazdıklarını gözden geçirmesi ve düzeltmesi sağlanır. Sinıf düzeyine uygun yazım ve noktalama kuralları ile sinırlı tutulur"; "T.8.4.18. Cümlenin ögelerini ayırt eder"; "T.8.4.19. Cümle türlerini tanır. Kavramsal tanımlamalara girilmez"; "T.8.4.20. Fiillerin çatı özelliklerinin anlama olan katkısını kavrar. Kavram tanımlarına girilmeden anlamsal farklılıklara değinilir" (MEB, 2017, s. 51- 54).

2019 Türkçe Dersi Öğretim Programı'nda cümle bilgisi kapsamında değerlendirilebilecek kazanım ve açıklamalar da, 2017 öğretim programı ile hem numaralandırılma hem de yapılanış itibariyle birebir örtüşmekte olup, 8. sınıf düzeyinde ele alınmıştır. Çalışmanın bu bölümünde bu programlarda tespit edilen ve bu çalışma kapsamında incelenen ders kitabında etkinlik çözümlemeleri gerçekleştirilirken göz önünde bulundurulan kazanım ve açıklamalara değinmek yerinde olacaktır.

Bu kazanımlardan ilk ikisi programda 8. sınıf "Okuma Becerisi/ Söz Varlığı” alt başlığında yer verilen "T.8.3.5. Bağlamdan yararlanarak bilmediği kelime ve kelime gruplarının anlamını tahmin eder. a) Ögrencilerin tahmin ettikleri kelime ve kelime gruplarını ögrenmek için sözlük, atasözleri ve deyimler sözlüğü vb. araçları kullanmaları sağlanır. b) Öğrencinin öğrendiği kelime ve kelime gruplarından sözlük oluşturması teşvik edilir" ve "T.8.3.6. Deyim, atasözü ve özdeyişlerin metne katkısını belirler" (MEB, 2017, s. 51; MEB, 2019, s. 48) kazanımlarıdır. Kelime grupları, alanyazında cümle bilgisi alanı kapsamında değerlendirilen konu başlıklarından biri olduğundan; deyim, atasözü ve özdeyişler; yapılanış olarak cümle kuruluşunda oluşları ve anlam bakımından taşıdıkları yoğun, soyut, mecaza dayalı ve üst düzey yansılarıyla bu çalışmada cümle bilgisi kapsamında ele alınması gereken konulardan biri olarak değerlendirilmiştir.

Programda aynı alt başlıkta yer alan bir diğer kazanım ve bu kazanıma ait açıklama ifadeleri şu şekildedir: "T.8.3.7. Metindeki söz sanatlarını tespit eder. Benzetme (teşbih), kişileştirme (teşhis), konuşturma (intak) ve karşıtlık (tezat), abartma (mübalağa) söz sanatlarının belirlenmesi sağlanır" (MEB, 2017, s. 51; MEB, 2019, s. 48). Cümleye, taşındığı yapı birimleri ile yeni anlam boyutları kazandıran söz sanatları, bu temel niteliklerinden ötürü bu çalışmada cümle bilgisi kapsamında değerlendirilmesi gereken bir alt alan olarak değerlendirilmiştir. 
Aynı alt başlıkla programa yansıtılan bir diğer kazanım ve açıklamasında bu çalışmada cümle bilgisi kapsamında ele alınması gerektiği belirtilen anlatım bozuklukları üzerinde durulmuştur. Ancak burada belirtilmesi gereken bir husus vardır. Kazanıma ait açıklamada sadece dil bilgisi yönünden anlatım bozuklukları üzerinde durulmuş olmasına karşın bu çalışmada cümlede yapı ve anlam bakımından üzerinde durulması gereken bütün anlatım bozukluğu etkinlikleri çalışma kapsamına dâhil edilerek çözümlenmiştir: "T.8.3.8. Metindeki anlatım bozukluklarını belirler." (Dil bilgisi yönünden anlatım bozuklukları üzerinde durulur) (MEB, 2017, s. 51; MEB, 2019, s. 48).

Okuma/ Söz Varlı̆̆ı başlığında programa taşınan bir diğer kazanım ve açıklaması, sözcük gruplarından biri olan fiilimsilere yaslanmaktadır: "T.8.3.9. Fiilimsilerin cümledeki işlevlerini kavrar. (Fiilimsilerin türleri fark ettirilir. Ekler ezberletilmez)." (MEB, 2017, s. 51; MEB, 2019, s. 48). Karahan'a göre fiilimsilere; yani bir isim-fiil, sıfat-fiil ya da zarf-fiile bağlı tamlayıcı veya tamlayıcılardan kurulan sözcük grupları olan isim-fiil, sıfat-fiil ve zarf-fiil gruplarında ana unsur olan isim-fiil, sıfat-fiil ve zarf-fiil sonda bulunur ve fiile dayalı bütün gruplarda olduğu gibi bu gruplarda da yüklem görevi yapan isim-fiil, sıfat-fiil ve zarf-fiilin anlamı; özne, nesne, yer tamlayıcısı ve zarf adı verilen ögelerle tamamlanır: "Onu (belirtili nesne)/ biraz sonra çekeceği acıya (yer tamlayıcısı)/ hazırlamak (yüklem): isim-fiil grubu" örneğinde olduğu gibi. Yüklem olan isim-fiil, sıfat-fiil ve zarf-fiil; yargı bildirmez (Karahan, 2018, s. 53- 59). Bu çalışmada fiilimsilere yaslanan etkinliklerin çözümlenmesi süreçlerinde Karahan tarafindan ortaya konulan bu veriler, esas kabul edilmiştir.

Okuma/ Söz Varlığı başlığı altında programa yansitılan "T.8.3.10. Geçiş ve bağlantı ifadelerinin metnin anlamına olan katkısını değerlendirir. (Oysaki, başka bir deyişle, özellikle, kisaca, böylece, ilk olarak ve son olarak ifadeleri üzerinde durulur).” (MEB, 2017, s. 51; MEB, 2019, s. 48) kazanım ve açıklaması; cümleler arası anlam ilişkilerine yaslanan geçiş ve bağlantı ifadeleri üzerinde durulması nedeniyle bu çalışmada cümle bilgisi kapsamında ele alınması gereken bir kazanım ve açılama olarak değerlendirilmiştir.

“T.8.3.15. Metinle ilgili sorular sorar" kazanımının da cümle bilgisi kapsamında ele alınması mümkündür. Çünkü soru cümleleri, anlamına göre cümle türlerinin alt başlıklarından biri olarak değerlendirilmektedir (MEB, 2017, s. 51; MEB, 2019, s. 48).

Programa Okuma/ Anlama başlığında yansıtılan “T.8.3.21. Metnin içeriğini yorumlar. a) Yazarın olaylara bakış açısının tespit edilmesi sağlanır. b) Metindeki öznel ve nesnel yaklaşımların tespit edilmesi sağlanır. c) Metindeki örnek ve ayrıntılara atıf yapılması sağlanır." (MEB, 2017, s. 52; MEB, 2019, s. 49) kazanım ve açıklaması, metinde yer alan cümleler arası etkileşime yaslandığından, yazarın olaylara bakış açısını yansıtan, metne öznel ve/ya nesnel nitelik kazandıran cümlelerin tespitini gerekli kıldığından, metnin içeriğinin yorumlanması sürecinde metindeki örnek ve ayrıntılara atıf yapılması süreci ile gerçekleştirilebileceğinden bu çalışmada cümle bilgisi kapsamında değerlendirilmiştir.

Okuma/ Anlama başlı̆ğ altında programa yansıtılan "T.8.3.25. Okudukları ile ilgili çıkarımlarda bulunur. Neden- sonuç, amaç- sonuç, koşul, karşılaştırma, benzetme, örneklendirme, abartma, nesnel, öznel ve duygu belirten ifadeler üzerinde durulur." (MEB, 2017, s. 52; MEB, 2019, s. 49) kazanım ve açıklaması ile anlam bakımından cümle türlerine gönderimde bulunulduğundan, bu çalışmada cümle bilgisi alanına dâhil edilebilecek bir kazanım ve açıklama olarak kabul edilmiştir.

Yazma başlığ 1 altında programa yansıtılan "T.8.4.7. Yazılarını zenginleştirmek için atasözleri, deyimler ve özdeyişler kullanır.", "T.8.4.15. Yazılarında uygun geçiş ve bağlantı ifadelerini kullanır. (Oysaki, başka bir deyişle, özellikle, ilk olarak ve son olarak ifadelerinin kullanılması sağlanır).", "T.8.4.16. Yazdıklarını düzenler. a) Dil bilgisine dayalı anlatım bozuklukları bakımından yazdıklarını gözden geçirmesi ve düzeltmesi sağlanır. b) Metinde yer alan 
yazım ve noktalama kuralları ile sınırlı tutulur (2017 programında kazanıma yönelik açıklama kısmı a ve b maddelerine ayrılmamıştır. Ayrıca açıklamanın son kısmı 2019 programından farklı olarak şu şekilde tamamlanmıştır: Sinıf düzeyine uygun yazım ve noktalama kuralları ile sinırlı tutulur)", "T.8.4.18. Cümlenin ögelerini ayırt eder.", "T.8.4.19. Cümle türlerini tanır. (Kavramsal tanımlamalara girilmez).", "T.8.4.20. Fiillerin çatı özelliklerinin anlama olan katkısını kavrar. (Kavram tanımlarına girilmeden anlamsal farklılıklara değinilir).” (MEB, 2017, s. 53- 54; MEB, 2019, s. 50) kazanım ve açıklamaları; cümle kuruluşundaki atasözü, deyim ve özdeyişler üzerinde durulması, cümleler arası geçiş ve bağlantı ifadelerinin konu edilmesi, anlatım bozuklukları, cümle ögeleri, cümle türleri ve fiillerde çatı konularını yansılaması bakımından bu çalışmada cümle bilgisi kapsamında değerlendirilmiş ve gerçekleştirilen etkinlik çözümlemesi süreçlerinde bu kazanım ve açıklamalarına gönderimde bulunulmuştur.

\section{Araştırmanın Amacı}

Bu çalışmanın amacı, 8. Sinıf Türkçe Ders (MEB, 2017a), Öğrenci Çalışma (MEB, 2017b) ve Ögretmen Kılavuz Kitabı'ndaki (MEB, 2017c) altı temada yer alan okuma ve dinleme/ izleme metinlerinin işleniş süreçlerine yönelik oluşturulmuş cümle bilgisi etkinliklerinin tespit edilmesi ve eleştirel bir bakışla yorumlanıp değerlendirilmesidir.

\section{Araştırmanın Yöntemi}

Araştırmada nitel araştırma yöntemlerinden betimsel yöntem kullanılmıştır. "Betimsel çalışmalar, verilen bir durumu aydınlatmak, standartlar doğrultusunda değerlendirmeler yapmak ve olaylar arasında olası ilişkileri ortaya çıkarmak için yürütülür" (Çepni, 2009). Çalışma, betimsel (descriptive) araştırma türlerinden biri olan tarama modelinde (Büyüköztürk, 2010, s. 21) gerçekleştirilmiştir. "Tarama modelleri, geçmiş̧e ya da hâlen var olan bir durumu var olduğu şekliyle betimlemeyi amaçlayan araştırma yaklaşımlarıdır. Araştırmaya konu olan olay, birey ya da nesne, kendi koşulları içinde ve olduğu gibi tanımlanmaya çalışılır. Onları, herhangi bir şekilde değiştirme, etkileme çabası gösterilmez. Bilinmek istenen şey vardır ve oradadır. Önemli olan, onu uygun bir biçimde gözleyip belirleyebilmektir" (Karasar, 1994, s. 77).

\section{Araştırmanın İncelenen Dokümanları}

Araştırmada 8. Sinıf Türkçe Ders (MEB, 2017a), Öğrenci Çalışma (MEB, 2017b) ve Öğretmen Kılavuz Kitabı (MEB, 2017c); birer doküman kabul edilmiş ve bu kitaplardaki cümle bilgisi etkinlikleri incelenmiştir.

\section{Verilerin Toplanması ve Analizi}

Verilerin toplanması sürecinde doküman kabul edilen kitaplarda yer alan cümle bilgisine yönelik oluşturulmuş bütün etkinlikler tespit edilerek fişlenmiş, elde edilen verilerin analizi sürecinde ise tespit edilen bu etkinlikler 2017 ve 2019 Türkçe dersi öğretim programlarındaki kazanımlar ile cümle bilgisi alanyazınının sunduğu veriler ışığında yorumlanmış ve bunların hangi gerekçe ile cümle bilgisi kapsamında değerlendirilebileceği ortaya konulmaya çalışılmıştır. Bu süreçte yer yer bu etkinliklerin alanyazındaki güncel veriler ışığında nasıl güncellenebileceği konusuna da değinilmiş, çalışmanın sonuç bölümünde bu güncellemelere yapılandırmacı yaklaşım ile dil bilgisi öğretimi konusunda görüş ortaya koyan araştırmacıların verileri 1şı̆̆ında eklemeler yapılmıştır.

Yapılan tüm bu açıklamaların ardından 8. Sinıf Türkçe Ders (2017a), Öğrenci Çalışma (2017b) ve Ögretmen Kılavuz Kitabı'ndaki (2017c) altı temada yer alan okuma ve dinleme/ izleme metinlerinin işleniş süreçlerine yönelik olarak oluşturulmuş cümle bilgisi etkinliklerinin tespit edilmesi ve eleştirel bir bakışla yorumlanıp değerlendirilmesi sürecine geçilebilir. Bu süreçte 2017 ve 2019 Türkçe Dersi Öğretim Programı'nda cümle bilgisi kapsamında değerlendirilebilecek kazanım ve açıklamalar, yol gösterici temel birer ölçüt olarak kullanılmıştır. Çalışmada 2017 yılında yayımlanan kitaplar incelenmiştir. En son çıkan ve 28.05.2019 tarihinde yayımlanan Türkçe 
ders kitabındaki cümle bilgisi etkinliklerinin ele alınacağı gelecekteki bir çalışma için araştırmacılara karşıllaştırma yapma olanağı sunabilecek bu çalışma, bu açıdan alanyazında önemlidir.

\section{Bulgular ve Yorum}

Aşağıda 8. Sinıf Türkçe Ders (2017a), Öğrenci Çalışma (2017b) ve Öğretmen Kılavuz Kitabı'ndaki (2017c) altı temada yer alan okuma ve dinleme/ izleme metinlerinin işleniş süreçlerine yönelik olarak oluşturulmuş cümle bilgisi etkinliklerinin tespit edilmesi ve eleştirel bir bakışla yorumlanıp değerlendirilmesine ilişkin bulgulara yer verilmiştir.

\section{Tema: Okuma Kültürü}

Temada "Kitaplarla Kurulan Dostluk" (şiir), "Okuma Serüvenim Nasıl Başladı?" (anı), "Sarı Traktör" (eleştiri) başlığını taşıyan üç okuma; "Benim Elli Beş Yıllık Türk Dili’m” başlığını taşıyan bir dinleme/ izleme ile "Okumak" (söyleşi) ve "Kütüphaneler" (anı) başlığını taşıyan iki serbest okuma metni olmak üzere toplam altı metin yer almaktadır.

"Kitaplarla Kurulan Dostluk" metninin 6. etkinliğinin a basamağında öğrencilere üç grup sözcük verilmiş ve onlardan bu sözcüklerde boş bırakılan yerlere ünlüler getirerek anlamlı sözcükler oluşturmaları istenmiştir: 1. Grup: başlar, yaşamaz, taşlayacak, suladık, bağışlamış; 2. Grup: başlayarak, yaşamak, taşlayan, sulayınca, bağışlayıp; 3. Grup: baş, yaş, taş, su, bağış.

Etkinliğin $\mathrm{b}$ basamağında öğrencilerden kendilerine etkinliğin a basamağında verilen sözcüklerden bir varlığın ismi olan sözcüklerin yanına $i$, hareket bildiren sözcüklerin yanına ise $f$ yazmaları istenmiş̧tir. Böylelikle öğrencilere 1. grupta yer alan çekimli fiiller ve üçüncü grupta yer alan isimler konusunda bir farkındalık kazandırılmak istenmiştir. Cümle bilgisinin cümlenin ögeleri boyutunun yüklem basamağında ele alınabilecek 1 . gruptaki çekimli fiiller, diğer grupta yer alan sözcüklerle karşılaştırma yapabilmelerine olanak tanınarak öğrencilere sunulmuş böylelikle onlarda cümle ögelerinden yükleme yönelik bir farkındalık kazandırılmak istenmiştir.

Etkinliğin c basamağında öğrencilere hangi gruptaki sözcüklerin açıkta kaldığı sorulmuş, öğrencilere böylelikle isim de fiil de olmayan, 2. gruptaki fiilimsiler (isim- fiil, sıfat-fiil ve zarffiiller) üzerine bir farkındalık kazandırılmak istenmiştir.

Etkinliğin ç basamağında öğrencilerden 2. gruptaki sözcükleri (fiilimsileri) kullanarak birer cümle kurmaları istenmiş böylelikle onlara edindikleri bilgileri uygulama sahasına taşıyı kendi orijinal cümlelerini oluşturabilme firsatı sunulmuştur.

Metnin 7. etkinliğinde öğrencilere Refik Halit Karay'ın Şeftali Bahçeleri öyküsünden iki paragraf verilmiş ve onlardan bu paragraflarda yer alan altı çizili sözcüklerin (giden, kasabadan, kurtulunca, uzanan, bahçeleri, geçerdi, tuttuğu, mevsimi, sürer, tepelerinde, pişirirken, toprakta, yoncalar, kabarırdı, gölgelik, uzanıp, dolup sindiği, işsizler, inerler, yıkandıktan, gelip, kurtularak, dökülürdü, pişip, oldukça, düşer, kaybolurdu) hangilerinin isim, hangilerinin fiil ve hangilerinin fiilimsi olduğuna karar vermeleri istenmiştir. Bu etkinlikle öğrenciler, hem cümle ögelerinden yüklem hem de sözcük gruplarından fiilimsiler hakkında karşılaştırma ve karar verme süreçlerine yaslanan bir cümle bilgisi farkındalığı elde edeceklerdir.

“Okuma Serüvenim Nasıl Başladı?” metninin 8. etkinliğinin a basamağında öğrencilere karışık olarak verilen sözcüklerden kurulu sekiz yapılanış verilmiş ve onlardan karışık olarak verilen sözcüklerden kurulu bu yapılanışlardan anlamlı cümleler oluşturmaları istenmiştir: "onHüseyin- dakikadır- koşuyor/ Hüseyin, on dakikadır koşuyor”. Böylelikle öğrencilere hem devrik ve kurallı cümle hem cümlede anlam hem de cümle ögelerinin sıralanış biçimi üzerine uygulamaya yaslanan çok boyutlu bir süreç sunulmuştur.

Etkinliğin a basamağında ögeleri karışık biçimde verilen yapılanışlara yaslanan etkinliğin b basamağında öğrencilerin bu yapılanışlarda koş- fiilinin aldığ 1 ekleri inceleyerek kendilerine

Turkish Studies - Social, 15(3) 
verilen soruları yanıtlamaları istenmiştir: koşuyor, koşarak, koşunca, koşmak, koşan, koşarken, koşuşla, koşar. Bu sorularda fiilin hangi biçiminin durum bildirdiği, hangisinin zaman anlamı taşıdığı, hangi biçiminin sıfat hangisinin isim görevinde kullanıldığ 1 ve hangi cümlede bu fiilin zaman ve kişi eki aldığ yoklanmıştır. Böylece öğrencilere fiillerin cümlede kişi ve zaman eki alarak çekimlenmiş biçimde ya da fiilimsi olarak yer alabileceği, fiilimsilerin işlevleri ve kullanım özellikleri sezdirilerek kavratılmaya çalışılmıştır.

Metnin 9. etkinliğinde öğrencilere Rauf Mutluay'ın Kitap Saygısı eserinden iki paragraf verilmiş ve öğrencilerden bu metindeki altı çizili sözcüklerden (anlatmıştım, tekrarlayacağım, bulunmuş, sokulduğu bir şehirde, ayıramamanın darlığını yaşayan bir evde, ödünç alarak, bozmamaya çalışarak, okumak, açılışlarını, bitirip, geri vermek, alınmış dergi koleksiyonları, izlemek, emek verilmiş bir madde olarak, çocukluk, doğan o basılı nesne, doğar, okuduğum zaman, çizdiğim, koyduğum notlar, olduktan sonra) fiilimsi olanları bulmaları ve bunların türlerine karar vererek örnekteki gibi yazmaları istenmiştir. Etkinlik bu yönüyle hem fiilimsi türlerinin birbirinden hem de fiilimsilerin çekimli fiillerden ayırt edilebilmesini gerekli kılmaktadır.

"Sarı Traktör" metninin 3. etkinliğinde cümlede anlam konusu üzerine yoğunlaşılmıştır. Öğrencilere metinden alıntılanan beş cümle verilmiş ve onlardan bu cümlelerden öznel olanların başına Ö, nesnel olanların başına ise $\mathrm{N}$ yazmaları istenmiştir. Verilen cümlelerden ikisi şu şekildedir: "On günde beş yüz lira para kazanmış $(\mathrm{N})$ ", "Talip Apaydın'ın gerçeği görüşü bana biraz eksik geldi (Ö)". Böylece cümlenin ögeleri ve sözcük gruplarından fiilimsiler konularına ek olarak cümle bilgisinin cümlede anlam boyutu da etkinliklere yansitılmak istenmiştir.

Metnin 6. etkinliğinde öğrencilere ikişer cümle biçiminde kurgulanmış sekiz yapılanış verilmiş ve onlardan bu yapılanışları kendilerine parantez içinde verilen zarf- fiil ekleriyle (-ınca, ken, -dığ 1 için, -1nca, -erek, -1p, -1r -maz, -alı, -madan) birleştirmeleri istenmiştir. Etkinlikte yer alan bu yapılanışlardan biri şu şekildedir: "Çağrıldığı yere yarım saat geç gitti. İșten kovuldu. (ınca)". Böylece öğrencilere fiilimsilerin Türkçe cümle bilgisine kazandırdığı anlatım kolaylığı, özgünlük ve işlevsellik üzerine bir farkındalık kazandırılmak ve ayrı cümleler biçiminde kurgulanan yapılanışların nasıl tek bir cümle biçimine getirilebileceği gözler önüne serilmek istenmiştir.

7. etkinlikte öğrencilere yine ikişer cümleden kurulu yapılanışlar verilmiş onlardan bu yapılanışları bu kez uygun fiilimsilerin neler olduğuna kendileri karar vererek tek bir cümle hâline getirmeleri istenmiştir. 6 ve 7. etkinlikler bir arada değerlendirildiğinde önceki etkinlikte öğrenciye doğrudan verilen zarf- fiil eklerine sonra gelen etkinlikte öğrencilerin kendilerinin karar vermelerinin istenmesiyle şekillendirilen bu tavır, yapılandırmacı yaklaşım ile bakışımlı bir yapılanış sergilemektedir.

Temada yer alan "Benim Elli Beş Y1llık Türk Dili'm" dinleme/ izleme metnine yönelik olarak oluşturulmuş Dinlediklerimi Değerlendiriyorum Formunda yer alan "Anlatımda çok uzun cümlelere yer verilmiştir" şeklindeki 3. ölçütün de -öğrencilerin dinledikleri/ izledikleri metinde yer alan cümlelerin uzunlukları hakkında değerlendirmeler yaparak çıkarımda bulunmalarını gerekli kıldığından- cümle bilgisi kapsamında değerlendirilmesi mümkündür.

Dinleme/ izleme metnine yönelik olarak oluşturulmuş 5. etkinliğin a, b ve c basamakları cümle bilgisinin sözcük grupları alt başlığına yönelik olarak şekillendirilmiştir. Etkinliğin a basamağında öğrencilerden unsurları iki ayrı sütunda verilmiş sözcükleri eşleştirerek sözcük grupları elde etmeleri istenmiştir: toplantıda bulunmak, yazı yazmak, boğazdan geçmek vb. Etkinliğin b basamağında, a basamağında eşleştirilen sözcüklerle yapılandırılan sözcük gruplarının cümlede kullanılması istenmiştir. Etkinliğin c basamağında ise sözcük gruplarının unsurlarının bir araya gelerek tek başlarına taşıdıklarından bambaşka bir anlam yüklendiği, bu sözcüklerin tek başlarına aynı anlamı vermek noktasında yetersiz kaldığı yönünde öğrencilere farkındalık kazandırılmasına ve bu durumun gerekçesinin araştırılmasına yönelik olarak bir soru yöneltilmiştir: 
"Kurduğunuz cümlelerdeki kelime gruplarını tek başlarına kullanabilir misiniz? Kelime gruplarını ayırıp tek başına kullandığınızda cümlelerin anlamlarında bir değişiklik olur mu? Niçin?"

$\mathrm{Bu}$ etkinlikte öğrencilerin cümlede fiilimsiye bağlı sözcük veya sözcük gruplarını bulmalarını sağlamak amacıyla sezdirme yöntemine başvurulacaktır. Öğretmenler tarafından da fiilimsilerin kendilerinden önceki veya sonraki sözcüklerle oluşturdukları sözcük gruplarına fiilimsi grubu denildiği, fiilimsi gruplarının isim- fiil grubu, sıfat- fiil grubu ve zarf- fiil grubu olmak üzere üçe ayrıldı $\breve{g} 1$ vurgulanacaktır.

Dinleme/ izleme metnine yönelik oluşturulmuş 6. etkinliğin a basamağında öğrencilere on üç cümle verilmiş ve onlardan bu cümlelerde yer alan fiilimsi gruplarının altını çizmeleri istenmiştir: “Kazdağı'nın Adalar Denizi'ne bakan yamaçlarından birindeyim”. Etkinliğin b basamağında öğrencilerden a basamağında tespit ettikleri fiilimsileri türlerine göre (isim- fiil, sıfatfiil ve zarf- fiil) verilen tablodaki uygun yerlere yazmaları istenmiştir.

Tema sonunda yer alan değerlendirme formunun ç basamağında yer alan çoktan seçmeli sorular, cümle bilgisi konuları etrafinda şekillendirilmiştir. Birinci soruda seçeneklerde sunulan cümlelerden hangisinde kullanılan zarf- fiilin zaman anlamı taşıdığı, ikinci soruda seçeneklerde sunulan cümlelerde altı çizili eklerden hangisinin diğerlerinden farklı olduğu (yanmamıș kimse: sıfat- fiil eki), üçüncü soruda bir dörtlük verilerek bu dörtlükte kaç fiilimsi bulunduğu, dördüncü soruda seçeneklerde sunulan cümlelerden hangisinde fiilimsi kullanılmadığı, beşinci soruda seçeneklerde sunulan cümlelerin hangisinde fiilimsinin tamlama içerisinde kullanıldığı, altıncı soruda cümlelerden hangisinde fiilimsi bulunmadı̆̆ isimleşmiş olduğu, sekizinci soruda ise öğrencilere soru kökünde bir cümle verilerek seçeneklerde sunulan cümlelerden hangisinde soru kökünde yer alan cümlede kullanılan fiilimsi ile aynı türde olan bir fiilimsinin yer aldığı sorulmuştur.

\section{Tema: Atatürk}

Temada "İşte Onun Evrensellik Anlayışı" (anı), "Onuncu Yıl Nutku” (söylev), "Atatürk ve Bilim" (makale) başlığını taşıyan üç okuma, "Dil Devrimi”" (makale) başlığını taşıyan bir dinleme/ izleme, "Atatürk'te Millet Sevgisi" (anı) ve "Gazi Mustafa Kemal'in Balıkesir Hutbesi" (söylev) başlıklı iki serbest okuma metni olmak üzere toplam altı metin bulunmaktadır.

"Işste Onun Evrensellik Anlayışı" metninin 5. etkinliğinde öğrencilere on iki cümle verilmiş ve onlardan bu cümlelerde boş bırakılmış noktalı yerleri uygun fiilimsi ekleriyle örnekteki gibi doldurmaları istenmiştir: "Büyük şehirlerde oyun alanları giderek azalıyor". Kök ya da gövde hâlinde verilen fiillere uygun isim- fiil, sıfat- fiil ve zarf- fiil eklerini getirerek cümleyi uygun biçime dönüştürmeleri istenen öğrenciler, böylece hem fiilimsi eklerinin fiil kök veya gövdelerine getirildiği hem de cümleyi türlü anlam ilişkileri ile nasıl tamamladığı konusunda kendi karar verme süreçlerini işleterek bir farkındalık elde edeceklerdir.

6. etkinlikte öğrencilere fiilimsiler ile ilgili on cümle verilmiş ve onlardan bu ifadelerin doğru olanlarının başına $\mathrm{D}$, yanlış olanlarının başına ise $\mathrm{Y}$ yazmaları istenmiştir. Bu ifadelerden ikisi şöyledir: "Fiilimsi ekleri, fiil kök veya gövdelerine gelir", "Fiilimsilerin olumsuz biçimleri yoktur". Bu etkinlik vasıtası ile de yapılandırmacı yaklaşım ile bakışımlı biçimde öğrencilerin fiilimsiler ile ilgili çıkarımlarda bulunmaları amaçlanmış, önceki etkinlikler ile kazandırılmaya çalışılan fiilimsilere ait temel nitelikler pekiştirilmek istenmiştir. Böylece ezbere yaslı ve unutulma ihtimali yüksek doğrudan bilgi aktarımı süreçlerinin önüne geçilmesi amaçlanmıştır.

7. etkinlikte öğrencilere Şükrü Enis Regü’nün üç paragraflık kısa bir metni verilmiş ve onlardan metinde geçen fiilimsilerin altını çizmeleri ve hangi fiilimsi türü olduğunu yazmaları istenmiştir. Ancak bu kez öğrencilere hem fiilimsileri yazacakları hem de bu fiilimsilerin türüne karar verecekleri sütunların yer aldığı bir tablo sunulmamıştır. Etkinlik bu açıdan eleştirilebilir. 
Öğretmenler, bu etkinliğin gerçekleştirilmesi sürecinde kullanılabilecek bu tabloyu çalışma kâğıdı biçiminde tasarlayıp çoğaltarak etkinlik öncesinde öğrencilerle paylaşabilir.

8. etkinlikte öğrencilere altı çizili sözcüklerin yer aldığı on cümle verilmiş ve onlardan bu sözcüklerin isim mi yoksa fiilimsi mi olduklarını gerekçeleri ile açıklamaları istenmiştir. "Bu bölgede güzelliğiyle ünlenen birçok çağlayan bulunmaktadır/ isim". "Ekmek alması için babasının verdiği parayı düşürmüş/ isim", "Tarlalarına buğday ekmek isteyen çiftçiler, yağmurun yağmasını bekliyor/ fiilimsi". İsim ve fiilimsiler arasındaki farklılıkların bilincinde olmayı gerekli kılan, karar verme süreçlerinin işletildiği bu etkinlik; fiilimsiler üzerine öğrencilerin zihninde oluşturulmaya çalışılan şemalara yeni bir boyut eklenmesini amaçlamaktadır. Bu yönüyle de yapılandırmacı yaklaşıma göre dil bilgisi öğretimi süreçleri ile bakışımlı bir yapılanış sergilemektedir.

"Onuncu Yıl Nutku" metninin 6. etkinliğinin a basamağı cümle bilgisi alanının cümlenin ögeleri alt boyutunun özne- yüklem uyumu ve fiil çekim ekleri konuları ile bağlantılıdır. Etkinlikte öğrencilere üç cümle verilmiş ve onlardan bu cümleleri yandaki kutucukta verilen dolaş- fiilinin farklı şahıslara göre çekimlenmiş üç biçiminden uygun olanı ile tamamlamaları istenmiştir: dolaştım, dolaştılar, dolaştı. Etkinliğin b basamağında öğrencilerden cümleleri tamamlarken nelere dikkat ettiklerini/ gerekçelerini yazmaları istenerek süreç pekiştirilmiş ve öğrencilerin zihninde oluşturulmaya çalışılan şemaların kalıcı kılınması amaçlanmıştır.

7. etkinlikte öğrencilere dört cümle verilmiş ve onlardan bu cümleleri özne- yüklem ilişkisini dikkate alarak düzeltmeleri istenmiştir. Etkinlik, öğrencilerin öznesine göre fiil çatıları konusu merkezinde yüklemlerin etken ve edilgen olması konusunda da farkındalık sahibi olmalarını gerekli kılmaktadır: "Herkes okulun önündeki bahçede müdürü dinlemek için toplandılar", "O, başkanı olur olmaz şeylere çağırıyor, çokça rahatsız ediliyordu". Etkinlik, cümle bilgisi alanının özne- yüklem uyumsuzluğuna yaslanan anlatım bozuklukları boyutu ile de doğrudan ilişkili bir nitelik sergilemektedir.

“Atatürk ve Bilim” metninin 3. etkinliğinde öğrencilere numaralandırılmış yedi paragraf verilmiş ve onlardan bu paragrafların altında yer alan noktalı yerlere paragrafla ilgili ikiş̧er soru cümlesi yazmaları istenmiştir. Etkinlik, cümle bilgisi alanının anlamlarına göre cümle türlerinin soru cümlesi kısmında değerlendirilebilir. Öğrenciler, bu etkinlik vasıtasıyla cümlede anlam konusundaki bilgilerini bir arada düşünerek okudukları paragraflara yönelik kendi özgün soru cümlelerini kurgulayarak yazacak, böylece zihinlerindeki kuramsal verileri uygulama sahasına taşımış olacaklardır.

Cümle bilgisinin cümlede anlam alt alanı ile bağlantılı 5. etkinliğin a basamağında öğrencilere beş cümle verilmiş ve onlardan bu cümlelerin anlam ilişkisi bakımından amaç- sonuç ya da sebep- sonuç cümle türlerinden hangisine dâhil edilebileceğine karar vermeleri istenmiştir. "Arabanın yakıtı bitince yolda kaldık" (sebep- sonuç). "Babamı görmek için iş yerine gittim" (amaç- sonuç).

Etkinliğin b basamağ da cümlede anlam ile ilişkilidir. Öğrencilere sekiz cümle verilmiş ve onlardan bu cümleleri aralarındaki yakın anlamlılık ilişkilerini göz önüne alarak eşleştirmeleri istenmiştir. Öznel ve nesnel yargılı cümlelerin ardından öğrenciler, bu etkinlikle birlikte yakın anlamlı cümleler konusunda da zihinlerindeki cümle bilgisi şemalarına yeni şemalar eklemeye yönlendirilmiştir: "Bütün sanat eserleri kendine özgüdür". "Her sanat eseri kendi kurallarını kendisi ortaya çıarır".

"Dil Devrimi" dinleme/ izleme metninin 3. etkinliğinin a basamağında öğrencilerden metinle ilgili beş soru hazırlamaları, b basamağında ise hazırladıkları bu soruları cevaplamaları istenmiştir. Soru cümleleri, anlam bakımından sınıflandırılan cümle türlerinden biridir. Öğrenciler, bu etkinlikle birlikte hem metni anlamlandırmış hem bu metne yönelik olarak anlam bakımından soru cümleleri kurgulayarak yazmış hem de bu soruların cevaplarını yine kendileri oluştururken cümle bilgisi üzerine önceden oluşturmuş oldukları bilişsel şemaları kullanmış olacaklardır. 
Metnin 4. etkinliğinin ardından öğrencilere bir Yazmamı Değerlendiriyorum Formu sunulmuştur. $\mathrm{Bu}$ formda yer alan ölçütlerden "Yeni öğrendiğim kelime, kavram, atasözü ve deyimleri kullandım" ifadesini cümle bilgisi kapsamında değerlendirebilmek mümkündür. Çünkü burada yeni öğrenilen sözcük ve kavramlar ile birer sözcük grubu olarak değerlendirilebilecek atasözü ve deyimlerin kurulan cümleler vasıtasıyla oluşturulan yazılı metinlere taşınmış olması söz konusudur.

5. etkinlikte öğrencilere anlatımla ilgili bazı hatalar yapıldığı belirtilen yedi cümle verilmiş ve onlardan bu cümlelerdeki anlatımla ilgili hataları bulup düzeltmeleri istenmiştir. Etkinlik bu yönüyle cümle bilgisi alanının anlatım bozuklukları alt başlığında değerlendirilmeye uygundur. İlk cümlede verilen sözcüğün deyimde yanlış kullanımı, ikinci cümlede sıralanış ve mantık hatası, üçüncü cümlede yüklem eksikliği, dördüncü cümlede noktalama işaretlerinden virgülün gerektiği yerde kullanılmamış olması, beşinci cümlede bağlacın hatalı kullanımı, altıncı cümlede olasılık ve kesinlik bildiren ifadelere aynı cümlede birlikte yer verilmiş olması, yedinci cümlede ise gereksiz sözcük kullanımından kaynaklanan anlatım bozuklukları yapılmışır. Birinci cümle şu şekildedir: "Bize o kadar kızmıştı ki yüzünden dökülen bin parça oluyordu" (burada "dökülen" değil "düşen" sözcüğü kullanılmış olmalıydı).

6. etkinlikte öğrencilere altı cümle verilmiş ve onlardan bu cümlelerdeki anlatım bozukluklarının gerekçelerini yanlarında verilen noktalı yerlere yazmaları istenmiştir. Birinci cümlede özne- yüklem uyumsuzluğu, ikincisinde yer tamlayıcısı eksikliği, üçüncüsünde deyim yanlışlı̆̆ı, dördüncüsünde yanlış sözcük kullanımı, beşincisinde özne eksikliği ve altıncısında gereksiz sözcük kullanımından kaynaklanan anlatım bozuklukları yapılmışıtır. Birinci cümle şöyledir: "Okulda düzenlenen şiir yarışmasında Beyza ve ben ödül aldım" (Burada Beyza ve ben özneleri, "biz" zamirine karşıllı geldiğinden cümlenin yükleminin "ödül aldık" biçiminde çekimlenmiş olması gerekliydi).

7. etkinlikte öğrencilere altı cümle verilmiş ve onlardan bu cümlelerdeki anlatım bozukluklarını düzelterek cümleleri yanda verilen boşluklara yeniden yazmaları istenmiştir. "Onunla görüşmeyeli aşağı yukarı tam üç yıl oldu" şeklinde ifade edilen birinci cümlede ya olasılık anlamı veren "aşağı yukarı" ya da kesinlik anlamı veren "tam" ifadelerinden birinin cümleden çıkarılması gerekmektedir.

Tema Sonu Değerlendirme Soruları bölümü, cümle bilgisi kapsamında değerlendirilebilecek soruları da kapsamaktadır. Bölümün öğrencilerin kendilerine sunulan yönergeleri uygulaması ile şekillendirilen $C$ basamağının 1. sorusu âdeta fiilimsiler konusu üzerine kurgulanmış bir sözel mantık sorusu niteliğindedir. Öğrencilere numaralandırılan altı cümle verilmiş ve onlardan bu cümlelerden hareketle fiilimsilerle ilgili doğru- yanlış sorularının yer aldığ 1 tabloyu uygun biçimde tamamlamaları istenmiştir. Bu ifadelerden bazıları şunlardır: "3 numaralı cümledeki 'televizyonda' kelimesi fiilimsidir", "4 numaralı cümlede isim- fiil kullanılmamıştır", "2 numaralı cümledeki 'tanıdık' kelimesi sıfat- fiildir".

Soruların C.2. basamağında öğrencilere ikişer cümleden kurulu beş yapılanış verilmiş ve onlardan bu cümleleri uygun fiilimsi ekleriyle birleştirip örnekteki gibi tek cümle olarak yazmaları istenmiştir: "Ben biliyorum. Ali yarın okula gelmeyecek"="Ali’nin yarın okula gelmeyeceğini biliyorum".

Bölümde öğrencilere yöneltilen çoktan seçmeli soruların üçüncüsünde öğrencilere numaralandırılmış dört ifade verilmiş ve onlara bu ifadeler hangi biçimde sıralandığında anlamlı ve kurallı bir cümleye erişilebileceği sorulmuştur: I. dağlarla çevrilmiş bir vadiye kurulmuş, II. dünyanın çatısı Himalaya sıradağlarının himayesindeki bu küçük ülke, III. "Ana Kraliçe" anlamına gelen Everest Dağı'nı içeren, IV. Katmandu'ya iner inmez gülen gözlerle karşılıyor bizi... Doğru cevap: III- II- I- IV. 
4. soruda öğrencilere seçeneklerde sunulan özdeyişlerden hangisinde fiilimsi kullanılmadığı (Türkiye Cumhuriyeti'nin temeli kültürdür), 5. soruda seçeneklerde sunulan cümlelerden hangisinin sadece özne ve yüklemden kurulu olduğu (Gökyüzünü kara bulutlar gibi kaplayan kargalar uçuverdiler), 6. soruda ise hangi cümlenin yükleminin isim tamlaması kuruluşunda olduğu (Türk milleti olarak sahip çıktığımız TDK Atatürk'ün mirasıdır) sorulmuştur.

\section{Tema: Millî Kültür}

Temada “Türküler Dolusu” (şiir), "Evliya Çelebi” (biyografi), "Orta Oyunu” (anı) başlığını taşıyan üç okuma, "İhtiyar Çilingir" (hikâye) başlığını taşıyan bir dinleme/ izleme ve "Yunus Emre" (biyografi) ile "Bağlamacıya" (şiir) isimli iki serbest okuma metni olmak üzere toplam altı metin bulunmaktadır.

“Türküler Dolusu" metninin 1. etkinliğinin a basamağında öğrencilere dört deyim ile bu deyimlerin anlamları farklı sütunlar hâlinde verilmiş ve onlardan kendilerine verilen deyimler ile anlamlarını eşleştirmeleri istenmiştir: toz kondurmamak, alnını karışlamak, bıçak kemiğe dayanmak, aklı ermek. Öğrenciler, etkinliğin b basamağında a basamağında verilen deyimleri cümle içinde kullanacaklardır. Etkinlik, birer sözcük grubu olarak değerlendirilebilecek deyimlere yaslanan ve bu deyimlerin cümlede kullanımını da içine alan yönleri ile cümle bilgisi kapsamında değerlendirilmeye uygundur.

Cümle bilgisi alanının cümlede anlam alt basamağı kapsamında ele alınabilecek 2 . etkinlikte öğrencilere şiirden alıntılanan dört sonuç cümlesi, bu cümlelerin sonuna "çünkü" bağlacı eklenerek verilmiş ve öğrencilerden bu cümlelere uygun sebepler yazmaları istenmiştir. Alıntılanan bu cümlelerden ilki şöyledir: "Kitaplarda değil türkülerde ara Yemen'i çünkü...."

7. etkinliğin a basamağında öğrencilere bir kelime havuzu verilmiş ve onlardan şiirden öğrendikleri kelime, deyim ve atasözlerini bu havuza yazmaları istenmiştir. Deyim ve atasözleri birer sözcük grubu veya cümle olarak değerlendirildiğinde etkinliğin cümle bilgisi kapsamında ele alınması mümkündür.

Etkinliğin $\mathrm{b}$ basamağında öğrencilerden a basamağında kendilerine sunulan kelime havuzundan hareketle bir şiir yazmaları istenmiştir. Yeni ve özgün bir sanat ürünü ortaya koymayı gerekli kılan bu etkinlik, cümle bilgisi alanında yetkinliğin yanında estetik bir duyarlığı da gerekli kılmaktadır.

8. etkinliğin a basamağında öğrencilere "Türk halk müziği korosu, geçen hafta Atatürk Kültür Merkezi'nde bütün yörelerimizin türkülerini seslendirdi” cümlesi verilmiş ve onlardan bu cümleden hareketle "ne", "ne zaman" ve "nerede" sorularını cevaplamaları istenmiştir. Etkinliğin b basamağında ise öğrencilere a basamağında yer alan sorulara verilen cevapların bu cümleyi hangi yönlerden tamamladığ 1 sorulmuştur. Etkinlik cümle ögelerinden nesne, zarf ve yer tamlayıcısı üzerine yapılandırılmış olması yönüyle cümle bilgisi alanının cümlenin ögeleri alt başlığında değerlendirilebilir.

Cümlenin ögeleri ve bu ögelerin tespit edilmesi süreçlerinde kullanılan sorulara odaklanılan 9. etkinlikte öğrencilere altı cümle verilmiş ve onlardan bu cümlelerden "nerede, ne zaman, ne?" sorularının cevaplarının hepsini içeren cümleleri işaretlemeleri istenmiştir: "Bugün (zarf)/ Topkapı Sarayı'nda (yer tamlayıcısı)/ göz kamaştırıcı eserler (nesne)/ gördüm (yüklem)”.

10. etkinliğin a basamağında öğrencilere kısa bir metin verilmiş ve onlardan bu metinde geçen zarfları bularak altını çizmeleri, etkinliğin b basamağında ise buldukları bu zarfları birer cümlede kullanmaları istenmiştir. Etkinlik hem cümle ögelerinden zarflar üzerine şekillendirilmiş olması hem de tespit edilen zarfların birer cümlede kullanılmasını gerekli kılması yönüyle cümle bilgisi kapsamında değerlendirilebilir. 
"Evliya Çelebi" metninin 2. etkinliği, cümlede anlam konusunun öznel ve nesnel yargılı cümleler alt basamağı etrafında şekillendirilmiştir. Etkinlikte öğrencilere altı cümle verilmiş ve onlardan bu cümlelerden öznel olanların başına Ö, nesnel olanların başına ise $\mathrm{N}$ yazmaları istenmiştir: "Evliya Çelebi, 25 Mart 1611'de İstanbul'da Unkapanı'nda doğdu" (N), "Evliya Çelebi’nin Seyahatname'si bir macera romanı gibi herkesin zevk alacağı bir eserdir” (Ö).

Anlamına göre cümle türleri kapsamında değerlendirilebilecek 3. etkinlikte öğrencilerden metne yönelik üç soru yazmaları ve bu soruları cevaplamaları istenmiştir. Soru cümleleri, anlamına göre cümle türlerinden birine işaret ettiğinden bu etkinliği cümle bilgisi kapsamında değerlendirmek mümkündür.

4. etkinlikte öğrencilerden okunan metnin giriş, gelişme ve sonuç bölümlerinin hangi cümlelerle başladığını yazmaları istenmiştir. Böylece onlara bilgilendirici bir metnin planına yaslanan giriş, gelişme ve sonuç bölümlerinin tespit edilmesine ve bu bölümlerin anahtarı niteliğindeki cümlelerin farkında olunmasına dayalı bir süreç yaşatılmak istenmiştir.

Etkinliğin sonunda yer alan Okuduğum Metni Değerlendiriyorum formunda yer alan ifadelerden bazıları da cümle bilgisi açısından değerlendirilmeye uygundur: "1. Metinde cümleler çok uzundur. 5. Yazarın demek istediği kolayca anlaşılıyor. 8. Yazar hep aynı şeylerden bahsederek fikir tekrarı yapmıştır. 9. Yazar, örnek ve alıntılardan yararlanmıştır. 11. Yazar anlatımda benzetmelerden yararlanmıştır".

7. etkinliğin a, b, c ve ç basamakları, cümlede vurgu konusu ve bu vurgunun genellikle yüklemden önceki kelime veya kelime grubunda olduğu kuralı etrafinda şekillendirilmiştir. Etkinliğin a basamağında öğrencilere yüklemden hemen önce gelen sözcüğün altının çizildiği, aynı ögelerden kurulu bir cümlenin ögelerinin yeri değiştirilmiş üç farklı biçimi verilmiş ve onlardan altı çizili bu sözcükleri daha vurgulu okumaları istenmiş̧tir: "Sararmış yapraklarla bahçeler sonbaharda süslenir. Sonbaharda bahçeler sararmış yapraklarla süslenir. Sonbaharda sararmış yapraklarla bahçeler süslenir".

Etkinliğin b basamağında öğrencilere vurgunun cümlede anlatımı kolaylaştırma gerekçesi, c basamağında vurgulu okunan sözcüklerin cümlenin neresinde yer aldığı, ç basamağında ise bu cümlelerde en çok önemsenen sözcük ya da sözcük gruplarının neler olduğu ve bu durumun gerekçesi sorulmuştur.

Cümle vurgusu konusunun pekiştirilmek istendiği 8 . etkinlikte öğrencilere beş cümle verilmiş ve onlardan bu cümlelerde vurgulu olması gereken ifadelerin altını çizmeleri, hangi ögelerin vurgulandığını cümlelerin altına yazmaları istenmiştir: "Harunlar köyünün dağlarını bembeyaz bulutlar kaplamıştı", "Köylülerin 'Kızılçalı' dedikleri dağ kayalardan oluşuyordu”, "Nevruz çiçekleri açmasına rağmen Kızılçalı'daki karlar erimedi", "İbibiklerin ötmesiyle Harunlarlılar yaylalarına sürülerini götürdüler", "Köylüler kışın hayvanlarını beslemek için ot biçtiler”.

"Orta Oyunu" metninin 2. etkinliğinin a basamağında öğrencilere üç cümle verilmiş ve onlardan bu cümlelerde yer alan zıt anlamlı sözcüklerin altını çizmeleri istenmiştir. Etkinliği bu yönüyle sözcükte anlam konusunda dâhil edilebilmekle birlikte $b$ basamağı etkinliğe cümle bilgisi kapsamında değerlendirilebilecek bir nitelik kazandırmaktadır. Bu basamakta öğrencilerden a basamağında tespit ederek altını çizdikleri zıt anlamlı sözcükleri aynı cümle içinde kullanmaları istenmiştir. Etkinlikte yer alan cümlelerden ilki şu şekildedir: "Bu oyunun dekoruna gelince 'yenidünya' denilen, yukarı ve dip kısmı ekseriya süs olsun diye küçük bir pano parçası hâlinde, üç dört aralıklı ve aşağıya kadar bütün ortası açık bir çeşit paravana idi”.

7. etkinliğin $\mathrm{a}, \mathrm{b}$ ve c basamakları; öznesine göre fiil çatıları ile etken ve edilgen çatılı cümleler konuları etrafında şekillendirilmiştir. Etkinliğin a basamağında öğrencilere altı cümle verilmiş ve onlara eylemin kim tarafından yapıldığı sorulmuştur. Etkinliğin $b$ basamağında 
öğrencilere hangi cümlelerde etkinliğin kim tarafından yapıldığının belli olmadığı sorulmuştur: "1. Sanatkâr eserleriyle topluma nasıl yaşamaları gerektiğini söyler. 2. Atatürk'ün fikirleri, sözleri tahlil edilmemiştir. 3. Sanatçı toplumun yaşayışına ayna tutar. 4. İnsanlar toprak medeniyeti ile huzura kavuşturulabilirler. 5. Toprak medeniyeti, fikri ileri topluma benimsetilir. 6. Sanatçı yeni dünya görüşü ortaya koyar". Etkinliğin c basamağında öğrencilere beş cümle verilmiş ve onlardan bu cümleleri karşılarındaki parantez içinde yer alan fiillerle uygun biçimde tamamlamaları istenmiştir: "Bazı sanatkârlar topluma ." (yol göster-).

8. etkinlikte öğrencilere on cümle verilmiş ve onlardan bu cümlelerin fiillerini/ yüklemleri edilgen hâle getirmeleri istenmiştir: "Milletler sanatta ilerleyerek medeniyete ulaştılar", "Sanatta ilerlenerek medeniyete ulaş11ır".

"İhtiyar Çilingir" dinleme/ izleme metninin 2. etkinliğinde öğrencilere beş cümle verilmiş ve onlardan bu cümlelerde yer alan altı çizili sözcüklerin eş seslileriyle noktalı yerlere cümleler yazmaları istenmiştir: "Adamcağız benimle hiç meşgul olmuyor göründü”. Etkinlik, bu yönüyle hem sözcükte anlam hem de cümle bilgisi kapsamında değerlendirilebilir.

Cümle bilgisinin anlamına göre cümle türleri alt başlığında ele alınabilecek 3. etkinlikte öğrencilerden dinlenen hikâye metni ile ilgili beş soru cümlesi yazmaları istenmiştir.

10. etkinliğin $\mathrm{a}, \mathrm{b}$ ve c basamakları; cümle bilgisinin nesnelere göre fiil çatıları konusu etrafında şekillendirilmiştir. Etkinlikte öğrencilere yedi cümle verilmiş, etkinliğin a basamağında onlardan bu cümlelerin fiillerini ve fiilden etkilenen nesneleri tabloya uygun biçimde yazmaları istenmiştir. Bu cümlelerden ilk üçü şöyledir: "1. Güllerden birini elime alıp koklamaya başladım. 2. Saksıdaki çiçek yapraklarını sehpaya dökmüştü. 3. Çok çalışmazsak sınıfımızı geçemeyebiliriz". b basamağında bu cümlelerin nesne alabilenlerinin nesnesiz olarak yeniden yazılması, c basamağında ise öğrencilerin bu cümlelerden hareketle fiilleri geçişsiz olan cümleler yazmaları istenmiştir.

11. etkinlik hem özne hem nesne bakımından fiil çatıları konusu etrafında şekillendirilmiştir. Etkinlikte öğrencilere 10 cümle verilmiş ve onlardan bu cümlelerin fiillerinin/ yüklemlerinin özne ve nesne bakımından çatı özelliklerini etkinlikte kendilerine verilen tabloya uygun biçimde işaretlemeleri istenmiştir: "Akşam vakti çocukları parka götürmüştüm” (öznesine göre etken ve nesnesine göre geçişli).

Tema sonunda yer alan Değerlendirme Soruları arasında cümlenin ögeleri, özellikle yardımcı ögeler ile fiilde çatı konusu etrafında şekillenen sorular yer almaktadır. Soruların B basamağında öğrencilere beş cümle verilmiş ve onlardan bu cümleler arasından yardımcı öge kullanılan cümleleri işaretlemeleri istenmiştir: "Anadolu'da, susuz toprakların yanık bağrından, büngül büngül kaynayan pınarlar vardır", "Karacaoğlan, Anadolu'nun her genç kızında ayrı bir güzellik görür", "Ahiliğin her köyde, her kasabada ve şehirde, ocakları, odaları ve tekkeleri vardır".

Soruların C basamağında öğrencilere beş cümle verilmiş ve onlardan bu cümlelerin çatı özelliklerini karşılarına yazmaları istenmiştir: "Kaşıkçılık el sanatı, hâlâ varlığını sürdürüyor (etken/ geçişli)", "Kırk gün, kırk gece düğün olmuş (etken/ geçişsiz)", "Karş1lıklı mâni atışmalarının yapıldığ 1 toplantılar düzenlenirdi (edilgen/ geçişsiz)".

Soruların Ç basamağında yer alan çoktan seçmeli soruların üçüncüsünde öğrencilere soru kökünde anlamı verilen bir deyimin ne olduğu (yermek veya alay etmek amacıyla birinin kötü veya yanlış davranışını sürekli söylemek/ diline düşmek), dördüncü soruda hangi cümlenin ögelerine yanlış ayrıldığ 1 (Geçen hafta tanıştı̆̆1/adamı/şehir meydanında/görmüştü.), beşinci soruda cümlelerin hangisinde vurgulanan ögenin yer tamlayıcısı olduğu (İnce Mehmet birdenbire taş1 dereye attı.), altıncı soruda hangi cümlenin yükleminin geçişsiz (Harman vakti geldiğinde 
komşularımıza yardım ederiz.), yedinci soruda ise edilgen çatılı (Konser salonunda müzisyenler hakkında bilgi verildi.) olduğu sorulmuştur.

\section{Tema: Kişisel Gelişim}

Temada "Empati ile Yaşamak" (deneme), "Karanfiller ve Domates Suyu" (hikâye), "Martı" (roman) başlıklarını taşıyan üç okuma, "Su Gibi" (şiir) isimli bir dinleme/ izleme, "Hellen Keller" (biyografi) ve "Adam Olmak" (şiir) başlığını taşıyan iki serbest okuma metni olmak üzere toplam altı metin bulunmaktadır.

"Empati ile Yaşamak" metninin 1. etkinliğinde yeni öğrenilen sözcüklerin cümlede kullanımı süreçleri merkeze alınmıştır. Öğrencilerden metinde geçen anlamını bilmedikleri iki sözcük belirlemeleri, bu sözcüklerin anlamını bağlamdan hareketle tahmin etmeleri, sözlük anlamlarını bulup yazmaları ve bu sözcükleri birer cümlede kullanmaları istenmiştir.

2. etkinliğin a ve b basamakları birer sözcük grubu olarak değerlendirilebilecek deyimler ile bunların cümlede kullanımına odaklanmıştır. Etkinliğin a basamağında tablo ile deyim anlamları verilmiş ve öğrencilerden bu anlamların metinde kullanılmış hangi deyimlere ait olduğu sorulmuştur. Etkinliğin b basamağında ise öğrencilerden tespit ettikleri bu deyimleri birer cümlede kullanmaları istenmiştir.

Anlam bakımından cümle bilgisi konusu ekseninde şekillenen 4. etkinlikte öğrencilerden okudukları metinle ilgili üç soru cümlesi yazmaları istenmiştir.

Cümlede anlam konusunun öznel ve nesnel anlamlı cümleler alt başlığı ile şekillendirilebilecek 5 . etkinlikte öğrencilere beş cümle verilmiş ve onlardan bu cümlelerin anlam bakımından öznel ya da nesnel olup olmadığına karar vermeleri istenmiştir.

5. etkinlik sonrasında yer alan Akran Değerlendirme Formundaki ölçütlerden "Canlandırma sırasında yeni öğrendiği kelime, kavram, deyim ve atasözlerini kullandı" ifadesinin de cümle bilgisi konu alanı kapsamında değerlendirilmesi mümkündür. Bu duruma gerekçe olarak hem deyim ve atasözlerinin birer sözcük grubu veya cümle olarak değerlendirilebilmesi hem de ifadede adı geçen bütün yapılanışların sözel dile aktarılarak cümlede kullanılması süreçleri etkili olmuştur.

6. etkinliğin a basamağında öğrencilere cümle kuruluşunda bir atasözü olan "İğneyi kendine çuvaldızı başkasına batır" atasözü verilmiş ve onlardan bu yapılanışın zihinlerinde yaptığı çağrışımları noktalı yerlere yazmaları istenmiştir.

Yüklemin türüne göre cümle çeşitleri konusu etrafinda şekillenen 7. etkinlikte öğrencilere on bir cümle verilmiş ve onlardan bu cümlelerin yüklemlerinin türünü örnekteki gibi karşılarına yazmaları istenmiş̧ir. Verilen cümlelerden ilki şu şekildedir: "Kardan daha beyaz köpüklü sularda yıkandılar" (fiil cümlesi). Benzer konu etrafında düzenlenen 8. etkinlikte öğrencilere on iki cümle verilmiş ve onlardan bu cümleleri yüklemlerinin türüne göre adlandırarak ilgili kutucuklara yazmaları istenmiştir: "Orada insanların dertleşerek mutlu yaşadıklarına inanıyorum” (fiil cümlesi).

7 ve 8 . etkinlikten bir adım öte ve daha üst düzey karmaşık bir beceri gerektiren 9 . etkinlikte öğrencilere on cümle verilmiş ve onlardan bu cümlelerin özelliklerini (anlamına ve yükleminin türüne göre hangi cümle çeşidine dâhil olduklarını) örnektekine benzer biçimde karşılarına yazmaları istenmiştir: "Her şeyin başı sağlıtır" (olumlu/ isim cümlesi).

"Karanfiller ve Domates Suyu" metninin 6. etkinliğinde cümlede yüklem sayısı, fiilimsiler ve bağlaçlar konusu üzerinde durulmuştur. Etkinlikte öğrencilere altı cümle verilmiş a basamağında onlara hangi cümle/ler/de tek yüklem, b basamağında çok yüklem, c basamağında fiilimsi, ç basamağında ise bağlaç bulunduğu sorulmuştur. Bu cümlelerden içinde fiilimsi olanlar 3 ve 6 . cümlelerdir: "Fenerin ışığı bir an kadının yüzünde durup geçti", "O, kendisini dinlemeyen adama sert bir bakış firlattı".

Turkish Studies - Social, 15(3) 
7. etkinlikte öğrencilere yirmi sekiz cümle verilmiş ve etkinlikte kendilerine verilen tabloya bu cümleleri yapı bakımından özelliklerini (tek yüklemli, fiilimsi bulunan, birden çok yüklemli, bağlacı olan) uygun biçimde işaretlemeleri istenmiştir. Bu cümlelerden içerisinde fiilimsi buluna cümleler; 3, 7, 14, 15, 16, 18 ve 26. cümlelerdir: "26. En pembelerini tahtaya gecirirken fes rengine boyad1".

"Martı" metninin 6. etkinliğinde öğrencilere Ahmet Muhip Dıranas'ın Şehrin Üstünden Geçen Bulutlar ve Olvido şiirleri verilmiş, etkinliğin a basamağında bu metinlerde yüklemlerin yeri, b basamağında ise bu durumun şiirin okunuşunu nasıl etkilediği sorularak devrik yapılı cümlelerin şiir diline sunduğu sanatsal müzikalite vurgulanmak istenmiştir.

Yükleminin yerine göre cümle çeşitleri konusu etrafında şekillenen 7. etkinlikte öğrencilere Ziya Osman Saba'nın Sebil ve Güvercinler şiiri verilmiş ve onlardan bu şiirde yer alan devrik cümleleri kurallı hâle getirmeleri istenmiştir: "Çözülen bir demetten indiler birer birer/ Çözülen bir demetten birer birer indiler".

"Su Gibi" dinleme/ izleme metninin 6. etkinliğinin sonunda yer alan Yazdığım Metni Değerlendiriyorum Formundaki ölçütlerden bazıları da cümle bilgisi kapsamında ele alınabilir: "Yeni öğrendiğim kelime, deyim ve atasözlerini kullandım" ölçütü deyim ve atasözleri birer sözcük grubu veya cümle olarak değerlendirilebileceğinden bu kapsamdadır.

Yapı bakımından cümle türleri konusu ile şekillenen 7. etkinlikte öğrencilere on cümle verilerek onlardan bu cümleleri yapı bakımından incelemeleri, tek yüklemli olanların yanına TYC, çok yüklemlilerinkine ÇYC ve içerisinde fiilimsi bulunanların yanına ise FBC yazmaları istenmiştir: "Zaman çok çabuk geçiyor" (TYC), "Seni düğünde görmüş̧ler, beğenmişler" (ÇYC), "Bu küçük yavrunun yaralarını görünce yüreği burkuldu" (FBC). Aynı konu etrafında şekillenen 8. etkinlikte öğrencilere sekiz cümle verilmiş ve onlardan bu cümlelerde boş bırakılan kısımları kutucukta kendilerine verilen bağlaçları (yalnız, veya, de, çünkü, ama, ancak, ki, ve) kullanarak uygun biçimde tamamlamaları istenmiştir: "Ardından çok bağırdım ancak sesimi duyuramadım".

Tema Değerlendirme Soruları bölümünde de cümle bilgisi kapsamında değerlendirilebilecek sorulara yer verilmiştir. A bölümünün 5. sorusunda öğrencilere bu bölümün başında kendilerine verilen metinde yer alan köylünün yaptığı davranışı özetleyen bir atasözü var ise bunu yazmaları istenmiştir: Sabreden derviş muradına ermiş. Deyim ve atasözleri, yapılanış bakımından birer sözcük grubu ya da cümle özelliği taşıdığından bu etkinliğin cümle bilgisi kapsamında değerlendirilmesi mümkündür.

B bölümünde öğrencilere altı cümle verilmiş ve onlardan bu cümleleri kutucukta yer alan deyimlerle (kendini dev aynasında görmek, canını dişine takmak, yoluna baş koymak, kulak tıkamak, burnu Kaf Dağı'nda olmak, gücü yetmek) doldurmaları istenmiştir: "Çevresinden gelen bütün olumsuz eleştirilere kulaklarını tıkayan Ali, sonunda istediğini gerçekleştirdi”.

Ç basamağında yer alan çoktan seçmeli soruların birincisinde seçeneklerde sunulanların hangisinin isim cümlesi olduğu: "Oturduğu ev, sokağın başındaydı",

İkinci soruda hangi cümlenin ögelerinin dizilişine göre diğerlerinden farklı olduğu "Sakla samanı, gelir zamanı" (devrik cümle),

Üçüncü soruda numaralandırılarak verilen cümlelerden hangisinin yapı bakımından diğerlerinden farklı olduğu: "Yoldan geçenleri seyrediyor" (Fiilimsi Bulunan Cümle),

Dördüncü soruda hangi cümlede birden çok yüklem bulunmadığı: “Ali’yi gördüğünü hatta onunla selamlaştığını söyledi”,

Beşinci soruda hangi cümlenin yapı bakımından diğerlerinden farklı olduğu: "Sonbahara girerken kış hazırlıklarını tamamlamıştık” (Fiilimsi Bulunan Cümle), 
Altıncı soruda "Yola çıkarken içimde hafif bir tedirginlik vardı" cümlesinin cümle bilgisi açısından temel özelliklerinin hangi seçenekte doğru olarak verildiği (kurallı, isim, olumlu, fiilimsi bulunan cümle),

Yedinci soruda "İş inada binince hiçbir şey yolunda gitmez" cümlesiyle ilgili seçeneklerde sunulan bilgilerin hangisinin söylenemeyeceği (bağlacı olan cümle) ve

Sekizinci soruda seçeneklerde sunulan cümlelerden hangisinin devrik, tek yüklemli isim cümlesi olduğu sorulmuştur: "O da tembel biriydi senin gibi".

\section{Tema: Toplum Hayatı}

Temada "Ergenekon Destanı" (destan), "Misafirliklerimiz" (söyleşi), "İmece" (anı) başlıklarını taşıyan üç okuma, "Türk Çayı" (söyleşi) başlığını taşıyan bir dinleme/ izleme ve "Tasmalı Güvercin" (fabl) ile "Seyfi Baba" (manzum hikâye) başlıklarını taşıyan iki serbest okuma metni olmak üzere toplam altı metin bulunmaktadır.

"Ergenekon Destanı" metninin 8. etkinliğinde öğrencilere altı kalıp ifade verilmiş ve onlardan bu ifadeleri cümlede kullanmaları istenmiștir. Kalıp ifadelerin birer sözcük grubu ya da cümle kuruluşunda olabileceği düşünüldüğünde etkinliğin cümle bilgisi kapsamında değerlendirilmesi mümkündür. Etkinlikte verilen kalıp ifadelerden üçü şu şekildedir: "Kuş uçmaz kervan geçmez yer", "şu sokak senin bu sokak benim", "bal tutan parmağını yalar".

9. etkinlikte öğrencilere bir cümle verilmiş ve onlardan bu cümlede bir sözcük grubu olarak değerlendirilebilecek altı çizilmiş kalıp ifadenin günümüzde kullanılan biçimini bulup bu ifadeyi bir cümlede kullanmaları istenmiştir: "Dağların içinde insan yolu düşmez sapa bir yer bulup orada yerleşelim diye karar verdiler" ( kuş uçmaz kervan geçmez yer).

"Misafirliklerimiz" metninin 2. etkinliğinde öğrencilere beş cümle verilmiş ve onlardan öznel yargı taşıyan cümlelerin başına Ö, nesnel yargı taşıyanların başına ise $\mathrm{N}$ yazmaları istenmiştir. Etkinlik, cümlede anlam konusu etrafında şekillendiği için cümle bilgisi kapsamında değerlendirilmiştir.

Cümlede anlam konusunun yoklandığı 3. etkinlikte öğrencilere iki cümle verilmiş ve onlardan bu cümlelerde anlatılmak istenen temel düşünceleri uygun yerlere yazmaları istenmiştir: "Pek az tanımaya firsat bulduğunuz göz aşinaları kapınızı çalabilir, sizin misafiriniz olabilirler".

Aynı konunun ele alındığı 6. etkinlikte öğrencilere on cümle verilmiş ve onlardan bu cümlelerin başına uygun olan anlam özelliklerinin numaralarını yazmaları istenmiştir: 1. olumlu, 2 . olumsuz, 3. varsayım, 4. ihtimal, 5. karşılaştırma, 6. öneri, 7. onaylama, 8. değerlendirme, 9. tanımlama, 10. benzetme. "Misafirlikler günümüzde hâlâ değerini korumaktadır/ 8 . değerlendirme", "Türklerin misafirliğinin bütün dünyada meşhur olduğu görüşüne katılıyorum/ 7. onaylama".

7. etkinlikte de cümlede anlam konusu ele alınmış, etkinlikte öğrencilere altı cümle verilmiş ve onlardan bu cümlelerin anlam özellikleri bakımından hangi cümle türüne dâhil olduklarını kutucuktan seçerek cümle karşısındaki boş bırakılan kısma yazmaları istenmiştir: karşılaştırma, değerlendirme, benzetme, olumsuz, tanımlama, onaylama, varsayım, öneri. "Misafirlik, samimi olmalıdır/ öneri”, "Şarkta misafirseverlik, âdeta kutsal bir vazifedir/ tanımlama".

"İmece" metninin 6. etkinliğinde öğrencilere beş deyim verilmiş ve onlardan bu deyimleri cümlede kullanmaları istenmiştir: gülmekten kırılmak, gözüne uyku girmemek, can atmak, tadı damağında kalmak, sıcak çökmek. Deyimler birer sözcük grubu olarak ele alınabileceğinden bu etkinliği cümle bilgisi kapsamında değerlendirmek mümkündür. 
7. etkinliğin a basamağında kendilerine verilen yabancı asıllı sözcükleri, Türkçe karşıllkları ile eşleştiren öğrencilerden etkinliğin b basamağında bu sözcüklerin Türkçe karşılıklarını cümlede kullanmaları istenmiştir: Aktivite- etkinlik, fragman- tanıtım filmi, aktüel- güncel. Etkinlik vasıtası ile öğrencilere hem dil bilinci kazandırılması hem de cümle bilgisi şemalarının harekete geçirilerek kendi özgün cümlelerini ortaya koyma becerisi edinmelerinin sağlanması amaçlanmıştır.

Cümlede anlam konusunun sebep- sonuç ve amaç- sonuç alt başlıklarına odaklanılan 9. etkinlikte öğrencilere yedi cümle verilmiş ve onlardan bu cümlelerin karşısına anlam ilişkisi bakımından uygun olanı yazmaları istenmiştir: "Tarla sahibi hasta olduğu için yardım imecesi yapıliyordu/ sebep- sonuç".

Benzer konu etrafinda şekillenen 10. etkinlikte öğrencilere on cümle verilmiş ve onlardan bu cümlelerden yakın anlamlı olanları eşleştirmeleri istenmiştir: "İmecelerde insanlar arasında birlik ve beraberlik bağları güçlenir// Birlikte iş yapan insanlar beraber hareket ederler".

“Türk Çayı" metninin 2. etkinliğinde öğrencilere yedi sözcük/ sözcük grubu verilmiş ve onlardan bu ifadeleri birer cümlede kullanmaları istenmiştir: asude, dingin, etnik, arkadaş canlısı, tavşan kanı, millî senfoni, müzik yelpazesi.

5. etkinlikte öğrencilere dinleme/ izleme metninden alıntılanan yedi cümle verilmiş ve onlardan bu cümlelerden öznel olanların başına Ö, nesnel olanların başına ise $\mathrm{N}$ yazmaları istenmiştir: "Türkiye'de günün her saatinde bir bardak çay içebilirsiniz/ N", "Türk çayı sıcaktır. Anadolu topraklarını ısıtan güneş gibi/ Ö”.

6. etkinlikte yer alan Dinlediklerimi Değerlendiriyorum Formunda yer alan ve metnin anlatımı ile ilgili olan bazı ifadelerin cümle bilgisi kapsamında değerlendirilmesi mümkündür: "Yazarın anlatmak istedikleri kolayca anlaşılmaktadır", "Yazar aynı şeylerden bahsederek fikir tekrarı yapmıştır", "Anlatımda benzetmelerden yararlanılmıştır", "Yazar düşüncelerini gözlemleri yoluyla anlatmıştır", "Yazar kişisel duygu ve düşüncelerini dile getirmiştir", "Yazar anlatımında sıklikla örneklerden yararlanmıştır".

Cümlede anlam konusu etrafında yapılandırılmış olan 11. etkinlikte öğrencilere numaralandırılmış on bir cümle ve harflendirilmiş yedi duygu verilmiştir. Onlardan bu cümleleri, cümlelere hâkim olan duygularla eşleştirmeleri istenmiştir: a) sitem, b) özlem, c) üzülme, ç) pişmanlık, d) abartma, e) şaşırma, f) beğenme. "Yillardır görmediğim memleketim burnumda tütüyor/ b) özlem", "Seni o kadar aradım ama sen beni bir kez olsun aramadın/ a) sitem".

Tema Değerlendirme Soruları bölümünde de cümle bilgisi etrafında şekillendirilen sorulara yer verilmiştir:

B.a. basamağında öğrencilere beş cümle verilmiş ve onlardan bu cümlelerde hâkim olan duyguları belirleyip karşılarına yazmaları istenmiştir: "Aldığınız ekmeğin, sütün, elmanın, domatesin, gazetenin hatırı kadar olsun bir muhabbet kurulmuyor/ sitem".

B.b. basamağında öğrencilere dört cümle verilmiş ve onlardan bu cümlelerle karşılarındaki kutucuklarda verilen anlam özelliklerini eşleştirmeleri istenmiştir: "Yürüyüşlerin, alışverişlerin daha sakin geçtiği bir ortamda yaşaman iyi olur/ öneri”.

C basamağında yer alan çoktan seçmeli soruların altıncısında seçeneklerde sunulan cümlelerden hangisinde bir öneride bulunulduğu (Anlattıklarınızı, yazıya aktarmanız iyi olacaktır), yedinci soruda ise numaralandırılarak verilen cümlelerden hangilerinin ihtimal bildirdiği (II. Adınızın açıklanması, maddi bir beklenti içine girmenize yol açabilir, III. Verdiklerimiz, her zaman bize maddi bir karşıl1k olarak dönmeyebilir) sorulmuş̧ur. 


\section{Tema: Zaman ve Mekân}

Temada "Güney İlleri” (şiir), "Bir Göl Nasıl Bin Göl Oldu?” (efsane), "Zamanı Kazanmak veya Kaybetmek" (Söyleşi) başlıklarını taşıyan üç okuma; "Kız Kalesi" (efsane) adlı bir dinleme/izleme ile "Türk Evinde Türk Dili Türk Dilinde Türk Evi" (deneme) ve "Yurdum" (şiir) başlıklarını taşıyan iki serbest okuma metni olmak üzere toplam altı metin bulunmaktadır.

"Güney İlleri” metninin 5. etkinliğinin a basamağında öğrencilere şiirden seçilmiş ve devrik cümlelerden kurulu beş cümle verilmiş ve onlardan bu cümleleri kurallı cümleler hâlinde yeniden yazmaları istenmiştir: "Dört mevsim bahardır güney illeri/ Güney illeri, dört mevsim bahardır". Etkinlik yükleminin yerine göre cümle türleri konusu etrafında şekillendirildiğinden cümle bilgisi kapsamında değerlendirilebilir.

Aynı konunun ele alındığı etkinliğin b basamağında öğrencilerden şiirin dizelerini [kurallı] cümleler biçiminde yeniden okumaları istenmiş ve onlara şiirin bu şekliyle kendilerinde aynı duyguları uyandırıp uyandırmadığını gerekçeleri ile açıklamaları istenmiştir.

Cümlede anlam konusu etrafinda yapılandırılan 11. etkinlikte öğrencilere dokuz cümle verilmiş ve onlardan bu cümlelerin taşıdıkları duyguları kendilerine kutucuklarda sunulan sekiz duygu (beğenme, sevinç, pişmanlık, şaşırma, sitem, özlem, üzüntü, acıma) arasından seçerek örnekteki ile benzer biçimde yazmaları istenmiştir: "Edirne'deki Selimiye Camisi o kadar güzeldi ki anlatamam/ beğenme", "Uzun zamandır çok sevdiğim arkadaşımı göremiyorum/ özlem", "Zavallı kuş, kanadından yaralandığı için uçamıyordu/ acıma".

"Bir Göl Nasıl Bin Göl Oldu?" metninin 1. etkinliğinin b basamağında öğrencilerden kendilerine etkinliğin a basamağında açıklamaları ile birlikte verilen altı deyimi birer cümlede kullanmaları istenmiştir: dizini dövmek, perişan etmek, niyet tutmak, dili dişi kilitlenmek, taban tepmek, gözleri parlamak. Etkinlik, birer sözcük grubu ya da cümle kuruluşunda olabilen deyimler konusuna odaklanılması ve bu deyimlerin cümlede kullanımının istenmesi nedeni ile cümle bilgisi kapsamında değerlendirilebilir.

Söz sanatlarının cümle anlamına katkısının ele alındığı 5. etkinliğin b basamağında öğrencilerden a basamağında örneklerle anlatılan söz sanatlarının anlatıma olan katkısını dikkate alarak söz sanatlarının geçtiği cümleler yazmaları istenmiştir. Cümlede anlam ve söz sanatları konusu etrafında şekillenen etkinlik, öğrencilerin kendi özgün cümlelerinin yazılmasının istenmesi ile zihinsel şemaların uygulama sahasına taşındığ bir boyutu yansıtmaktadır.

10. etkinlikte öğrencilere iki paragraflık bir metin verilerek onlardan bu metindeki anlatım bozukluklarını düzeltmeleri ve metni yeniden yazmaları istenmiştir: "Bu konuda herkesin fikir ve görüşünü almalıydım” koyu dizili sözcüklerden birinin cümleden çıkarılması gerektiği gibi.

"Zamanı Kazanmak veya Kaybetmek" metninin 5. etkinliğinde metnin dil ve anlatım ile içerik özelliklerini değerlendirmek amacıyla öğrencilere yöneltilen sorulardan ikisini sözcük sayısı açısından cümle ve cümlede anlam konuları ile ilişkili oldukları gerekçesi ile cümle bilgisi kapsamında değerlendirmek mümkündür: "Okuduğunuz metinde cümleler genellikle kaç kelimeden oluşmuştur?" ve "Metinde sebep- sonuç, amaç- sonuç ilişkileri kurulmuş mudur?"

8. etkinlikte öğrencilere sekiz cümle verilmiş ve onlardan bu cümlelerdeki anlatım bozukluklarının nedenleri ile cümlelerin doğru biçimlerini bırakılan boşluklara uygun biçimde yazmaları istenmiştir: "Hayat beklenmedik sürprizlerle insanları dener/ beklenmedik sözcüğü cümleden çıkarılmalıdır", "Spor yapmayanlar daha çok doktora gidiyor/ cümlenin sonu '... doktora daha çok gidiyor' biçiminde olmalıdır ", "Otobüs saplandığ çamurdan daha henüz çıkamad1/ 'daha' ya da 'henüz' sözcüklerinden biri cümleden çıkarılmalıdır’' gibi. 
"Kız Kalesi” metninin 4. etkinliğinde öğrencilere sonunda "çünkü” bağlacının yazılmış olduğu üç cümle verilmiş ve onlardan önce bu cümleleri tamamlamaları ardından da bu cümlelerdeki amaç ve sonuç ifade eden yargıları yazmaları istenmiştir.

7. etkinlikte öğrencilere bir metin verilmiş ve onlardan bu metinde boş bırakılan cümleleri metnin anlam bütünlüğünü dikkate alarak doldurmaları istenmiștir. Bağlamdan hareketle oluşan cümle anlamının dikkate alınması süreçleri ile tamamlanabilecek etkinlik, bu nedenle cümle bilgisi kapsamında değerlendirilebilir: Vaktiyle bugünkü İçel ilimizin bulunduğu bölgeye hâkim olan bir bey varmış. Bu beyin bir kızı dünyaya gelmiş. Bey, o devrin âdetine uyarak kızını bir kâhine götürmüş ve onun geleceği hakkında bilgi edinmek istemiş.

8. etkinlikte öğrencilere James Hughes'ın Kendini Tanı, Mutlu Ol metni verilmiş ve onlardan metinde yer alan anlatım bozukluklarını düzelterek metni yeniden yazmaları istenmiştir: "Fakat bazı beceriler ve yeteneklerle zenginleşmiş olduğumuzu bilmek dengemizi sağlar/ gereksiz sözcük kullanımı, 'beceri' ve 'yetenek' sözcüklerinden biri, bu cümleden çıkarılmalıdır” cümlesi gibi.

Tema Değerlendirme Soruları bölümünün A.1. basamağında öğrencilere iki deyim (dumanı üstünde, gözüne ilişmek) verilmiş, onlardan bu deyimlerin metindeki anlamlarını sözlükten bularak yazmaları ve bunları birer cümlede kullanmaları istenmiștir. Verilen bu deyimlerin birer sözcük grubu yapılanışında oluşları ile öğrencilerin bu deyimleri kendi özgün cümlelerinde kullanmaları süreçleri, bu etkinliğin cümle bilgisi kapsamında değerlendirilmesinin temel gerekçeleri olarak gösterilebilir.

C basamağında yer alan çoktan seçmeli soruların ilkinde Turgut Uyar'ın Nutuk şiirinde geçen "iki gözü iki çeşme" deyimi ile ne anlatılmak istendiği, beşinci soruda seçeneklerde sunulan cümlelerden hangisinde beğeni anlamı olduğu (Şair dediğin işte böyle olmalı), altıncı soruda hangi cümlede deyimin yanlış kullanıldığı (İşler o kadar karıştı ki seç pirincin taşını/ seç yerine ayıkla yüklemi kullanılmalıydı), yedinci soruda hangi cümlede anlatım bozukluğu olduğu (Yeni makinemle arkadaşlarımın resimlerini çekeceğim/ fotoğraflarını çekeceğim biçiminde cümle sonlandırılmalıydı) ve sekizinci soruda hangi cümlede yer tamlayıcısı eksikliğinden kaynaklı bir anlatım bozukluğu söz konusu olduğu sorulmuştur (Dostlarına gitmiş, yardım talep etmişti/ onlardan yardım talep etmişti).

\section{Sonuç}

8. Sinıf Türkçe Ders (2017a), Öğrenci Çalışma (2017b) ve Öğretmen Kılavuz Kitabı'ndaki (2017c) altı temada yer alan okuma ve dinleme/ izleme metinlerinin işleniş süreçlerine yönelik olarak oluşturulmuş cümle bilgisi etkinliklerinin tespit edilmesi ve eleştirel bir bakışla yorumlanıp değerlendirilmesi sürecinin ardından elde edilen sonuçları şöyle sıralamak mümkündür:

1. tema Okuma Kültürü’nde ağırlıklı olarak cümle ögelerinden yüklem, fiilimsiler (isimfiil, sıfat- fiil ve zarf- fiiller) ve fiilimsilerin cümlede kullanılması, cümlede anlam (öznel ve nesnel cümleler), yükleminin yerine göre cümle türleri (devrik ve kurall1), çekimli fiil ve fiilimsilerin işlev ve kullanım özellikleri açısından karşılaştırılması, fiilimsi türlerinin hem birbirinden hem de çekimli fiillerden ayrılan yönleri, birden çok cümlenin zarf- fiil ekleri ile birleştirilerek tek bir cümle hâline getirilme biçimleri ve fiilimsilerin Türkçe cümle yapısına kazandırdığ 1 anlatım kolaylığı, özgünlük ve işlevsellik; cümle uzunluğu, fiilimsi grupları (isim- fiil, sıfat-fiil ve zarf- fiil grubu) ve bunların birbirinden ayrılan tarafları, zarf- fiilin taşıdığ 1 anlamlar (zaman, sebep, vasıta, tarz vb.), isim- fiil, sıfat- fiil ve zarf- fiil ekleri, isimleşmiş sıfat- fiil konularına odaklanılmıştır.

2. tema Atatürk'te cümle bilgisi alanına dâhil edilebilecek olan konular; fiilimsi ekleri, fiilimsilerin karakteristik nitelikleri, fiilimsi türlerinin birbirinden ayırt edilmesi, isimler ile fiilimsiler arasındaki farklar, özne- yüklem uyumu açısından fiil çekim ekleri, öznesine göre fiil çatıları, cümlede anlam (öznel- nesnel, amaç- sonuç ve sebep- sonuç cümleleri, cümlelerde yakın 
anlamlılık), anlamına göre cümle türlerinden soru cümleleri, birer sözcük grubu ya da cümle yapılanışında olan atasözü ve deyimlerin öğrenciler tarafından gerçekleştirilen çalışmalarda ve etkinliklerde kullanılması, anlatım bozuklukları (sözcüğün deyimde yanlış kullanımı, cümlede sıralanış ve mantık hatası, yüklem eksikliği, noktalama işaretinin yanlış yerde kullanımı, bağlacın hatalı kullanımı, olasılık ve kesinlik bildiren ifadelere aynı cümlede yer verilmiş olması, gereksiz sözcük kullanımı, özne- yüklem uyumsuzluğu, yer tamlayıcısı eksikliği, yanlış sözcük kullanılması, özne eksikliği), birden çok cümlenin fiilimsi ekleri ile birleştirilerek tek bir cümle hâline getirilmesi, karışık verilen ifadelerin sıraya konularak anlamlı ve kurallı cümleler elde edilmesi, cümlenin ögeleri, sadece özne ve yüklemden kurulu cümleler, yüklemi isim tamlaması kuruluşunda olan cümleler, sözcük gruplarının yüklem olabilme biçimleridir.

3. tema Millî Kültür'de üzerinde durulan cümle bilgisi konuları; sözcük grubu ya da cümle yapılanışındaki deyimlerin anlamları ile eşleştirilmesi ve öğrenciler tarafından cümlede kullanılması, cümlede anlam (sebep- sonuç cümleleri ve bir cümle bağlayıcısı olarak 'çünkü'), metinlerden, birer sözcük grubu ya da cümle yapılanışında olan atasözü ve deyimlerin tespit edilerek bir atasözü ve deyimler havuzu oluşturulması, kelime havuzunda yer alan kelime, atasözü ve deyimlerin kullanılarak şiir yazılması, cümlenin ögeleri (temel ve yardımcı ögeler) ve bu ögelerin tespitinde kullanılan sorular (nesne/ ne?, zarf/ ne zaman?, yer tamlayıcis1/ nerede?), zarfların cümlede kullanılması, cümlede anlam (öznel ve nesnel yargılı cümleler), anlamına göre cümle türlerinden biri olan soru cümleleri (işlenen metne yönelik sorular oluşturulması), bilgilendirici bir metnin giriş- gelişme ve sonuç cümlelerinin tespit edilmesi, paragrafta anahtar cümlelerin farkında olunması, cümle uzunluğu, cümlede yazarın niyetinin anlaşılırlı̆ğ, paragrafta ya da metinde cümleler arası fikir tekrarı; cümlede benzetmelerden, örnek ve alıntılardan yararlanma; cümle vurgusu ve önemi, vurgunun cümledeki anlatımı kolaylaştırma işlevi, cümlede vurgulanan sözcük ve sözcük gruplarının konumu, cümlede vurgulanan ifadenin cümlenin hangi ögesi olduğunun tespit edilmesi, cümlelerde yer alan zit anlamlı sözcüklerin tespit edilmesi ve öğrenciler tarafından cümlede kullanılması, öznesine göre fiil çatıları (etken ve edilgen çatılı cümleler), yüklem kısmı boş bırakılan cümlelerin öğrencilere verilen fiillerin uygun biçimleri ile tamamlanması, etken cümlelerin edilgen hâle getirilmesi; cümlede altı çizili olarak verilen sözcüklerin eş seslileri ile yeni cümleler oluşturulması (hem sözcükte anlam hem de cümle bilgisi etkinliği); dinleme/ izleme metnine yönelik olarak soru cümlesi hazırlanması, nesnesine göre fiil çatıları (geçişli ve geçişsiz fiiller), deyimler ve anlamları, cümlelerin ögelerine ayrılma süreçleri, cümle ögelerinden yer tamlayıcısının vurgulandığı cümlelerdir.

4. tema Kişisel Gelişim'de cümle bilgisi alanına yönelik olarak etkinliklere yansıtılan konular; bağlamdan hareketle anlamı tahmin edilen ve sözlük anlamına erişilen sözcüklerin cümlede kullanılması, deyimlerin ve atasözlerinin cümlede kullanımı, işlenen metne yönelik soru cümlelerin hazırlanması, cümlede anlam (öznel ve nesnel yargılı cümleler), senaryo canlandırma esnasında deyim ve atasözlerinin kullanılması, atasözlerinin çağrışımlarının belirlenmesi; anlamına (olumlu ve olumsuz cümle), yükleminin türüne göre (isim ve fiil cümlesi), yapı bakımından (tek yüklemli/ TYC, çok yüklemli/ ÇYC, fiilimsi bulunan/ FBC, bağlaç olan cümle) ve yükleminin yerine göre cümle türleri (kurallı ve devrik cümle); devrik yapılı cümlelerin şiir diline sunduğu müzikalite, devrik cümlelerin kurallı hâle getirilmesi, birden çok cümleden kurulu yapılanışların anlam bakımından en uygun bağlaç kullanılarak birbirine bağlanması, bir öyküye yaslanan deyim ve atasözleri, cümlelerin uygun deyimlerle tamamlanmasıdır.

5. tema olan Toplum Hayatı bölümünde üzerinde durulan cümle bilgisi konularını şu şekilde sıralamak mümkündür: sözcük grubu kuruluşundaki kalıp ifadelerin cümlede kullanılması, kalıp ifadelerin günümüzde kullanılan biçiminin tespit edilmesi ve cümlede kullanılması, anlam bakımından cümle türleri (olumlu, olumsuz, varsayım, ihtimal, karşılaştırma, öneri, onaylama, değerlendirme, tanımlama, benzetme, öznel ve nesnel, sebep- sonuç, amaç- sonuç), yakın anlamlı cümleler, cümlede anlatılmak istenen temel düşünce, deyimlerin cümlede kullanılması, Türkçe karşılıkları ile eşleştirilen yabancı asıllı sözcüklerin cümlede kullanılması, sözcük ve sözcük 
gruplarının cümlede kullanılması, metin oluşturan ya da kurgulayan yazarın metnin cümlelerine yansıyan niyeti ve üslubu, cümleye hâkim olan duygulardır (sitem, özlem, üzülme, pişmanlık, abartma, şaşırma ve beğenme).

6. tema Zaman ve Mekân'da etkinliklere yansıtılan, cümle bilgisi kapsamında değerlendirilebilecek konular şunlardır: yükleminin yerine göre devrik olan cümlelerin kurallı biçimde yeniden yazılması, dizelerindeki devrik cümlelerin kurallı hâle getirildiği şiir metinlerinin yeniden okunduklarında okurda aynı duyguları uyandırıp uyandıramayacağ 1 sorunsalı ve bunun temel gerekçeleri, cümlelerin taşıdıkları duygular (beğenme, sevinç, pişmanlık, şaşırma, sitem, özlem, üzüntü, acıma), deyimlerin cümleye kattığı anlam ve öğrenciler tarafindan cümlede kullanılması, söz sanatlarının cümle anlamına katkısı ve cümlede kullanılması; anlatım bozuklukları, nedenleri ve düzeltilme biçimleri [olasılık ve kesinlik bildiren ifadelerin aynı cümlede birlikte kullanılması, sözcüğün yanlış yerde kullanılması, gereksiz sözcük kullanılması, anlamı karıştırılan sözcükler (fotoğraf- resim), yer tamlayıcısı eksikliği, deyimlerin yanlış kullanılması vb.]; sözcük sayısı açısından cümle, cümlede anlam (sebep- sonuç ve amaç- sonuç cümleleri), cümlede "çünkü" bağlacı ile kurulan amaç- sonuç ilişkileri, metinde yer alan cümlelerde boş bırakılan yerlerin metnin bağlamından hareketle doldurulması.

Dil bilgisi öğretiminin amacını kuramsal bilgi değil, öğrencilerin Türkçedeki anlama ve anlatma güçlüklerine yardım etmek, onlara uygulama gücü kazandırmak olarak tespit eden Göğüş (1978, s. 348- 352), bu öğrenme alanı için kullanılacak öğretim yönteminin de bu becerileri kazandırmaya yönelik olması gerektiğine vurgu yapar ve buradan hareketle dil bilgisi öğretim yöntemiyle ilgili dokuz temel ilke belirler: Dil bilgisi öğretiminde örneklerden kurallara ulaşılan gözleme dayalı bir tümevarım yöntemi izlenmelidir. Bu süreçte kuralların öğrencide birer beceri ve alışkanlık durumuna gelmesi için onlara alıştırmalar yaptırılmalıdır. Öğretmenin temel çıkış noktası, öğrencinin karşılaştığı dil sorunları olmalıdır; başka bir deyişle, öğrenci hangi kuralları bilmiyorsa, bunun ders konusu yapılması gereklidir. Kuralların öğretilmesinde öğrenciyi doyuracak, kuralı doğru kullanmaya yetecek derinlikte bilgi verilmelidir; sorunu açıklayacak, tanıtacak zengin örnekler, değişik durumlar üzerinde çalışılmalıdır; kural dışı kaymalar, aykırılıklar da yeterince işlenmelidir. Dil bilgisinin bütün sorunlan birbirinden bağımsız ve yalın olarak değil; tümce içinde ele alınmalıdır. Çünkü düşüncelerimiz, tümce olarak anlatılır ve tümce olarak biçimlenir; sorunlar da bu biçimlenmelerde, tümce içinde belirir. Dil bilgisi gözlemleri, alıştırmaları; yapay örnekler üzerinde yaptırılmamalı; incelenecek örnekler, yazarlardan seçilmelidir. Dil bilgisi dersi, başka ana dili etkinliklerine bağlı olarak okutulmalı; dil bilgisi ile okuma ve yazma çalışmalarının birlikte yürütülmesi sağlanmalıdır. Öğrencilerin ellerinde bir dil bilgisi kitabı bulunması yararlıdır; çünkü öğrenciler, kural, örnek ve alıştırma için bir kitaba başvurmak gereğini duyarlar; dil bilgisi sorunlarının bir defter üzerinde işlenmesi de gerekir; öğrenci, bu defterde örnekleri, çıkarılan kuralları, alıştırmaları bir arada bulabilmelidir. Her sınıfta geri öğrenciler, ayrıca yetiştirilmeli; ileri öğrencilerin ilgilerini karşılayacak çalışmalara da olanak hazırlanmalıdır (açıklamalar, kaynak gösterme vb. yollarla).

Sağır ve Demir Atalay, cümle bilgisi ve öğretimi sürecinin cümle çözümlemeleri basamağının dört aşamadan oluşan bir yol takip edilerek gerçekleştirilmesi gerektiğini ortaya koyarlar: I. Cümledeki kelime öbekleri/ sözcük grupları, isimleriyle tanınmalı ve belirtilmelidir; II. Cümle birden çok basit ya da birleşik cümleden oluşuyorsa "sıralı" ya da "bağlı" cümle dedikten sonra her bir basit ya da birleşik cümle, ayrı ayrı aşağıdaki maddelerde belirtildiği sıra ile çözümlenmelidir: III. Cümleyi oluşturan her bir kurucu görev ismi ile; yüklem, özne, dolaylı tümleç, nesne, zarf tümleci olarak belirtilmelidir. IV. Cümlenin, yükleminin çeşidi bakımından fiil cümlesi mi, isim cümlesi mi; yükleminin yeri bakımından devrik cümle mi, kurallı cümle mi; anlamı bakımından olumlu cümle mi, olumsuz cümle mi, soru cümlesi mi, ünlem cümlesi mi; yapısı bakımından da basit yapılı m1, birleşik yapılı mı olduğu belirtilmelidir (2016, s. 82). 
Aslan'a göre dil bilgisel konular (önad/ sıfat, adıl/ zamir, belirteç/ zarf, eylemsiler/ fiilimsiler vb.), o konuya ilişkin kuru bilgiler biçiminde anlatılmamalı; yaklaşım, kuralı derste işlenen metindeki örnekler yoluyla sezdirmek, anlama ve tanıma öğrencinin ulaşmasını sağlamak olmalıdır. Çocuk; öğretime kendi öznelliğiyle, özgünlüğüyle, istek ve edimleriyle katılmalıdır. Bu süreçte çocuğun her konuya olduğu gibi dil bilgisi konu alanına da eleştirel bakması, öğrenmeyi sorgulaması ve bu konuyu öğrenmenin kendisine ne gibi katkılar sağlayacağını bilmesi gereklidir. Cümle bilgisi konularının, örneğin fiilimsilerin öğretilmesi sürecinde öğretimin amacına ulaşabilmesi yani öğrencinin fiilimsileri doğru, yerinde ve işlevsel kullanabilmesi için öncelikle fiilimsilerin sıkça ve etkili kullanıldığı, çocuğun yaş ve gelişim düzeyine uygun nitelikli bir metnin seçilmesi ön koşuldur. Metni okuma ve anlamlandırma çalışmalarının ardından öğretmenin öğrencilerini bu yapıların metne neler kattı̆̆, ne gibi işlevler üstlendiği üzerine düşündürmesi gerekir. Bir sonraki adımda öğrencilere fiilimsilerin metinden kaldırıldığı durumda olabilecek/ karşılaşılabilecek sorunlar, örnekler yoluyla gösterilmelidir. Bütün bu çalışmaların sonunda fiilimsilerin önemi ve işlevi, iyi öğrenildiği durumda anlama ve anlatma becerilerine olabilecek katkıları öğrencilerle birlikte ortaya konulmalı ve bu yolda kurallara ulaşılmaya çalışılmalıdır: fiilimsiler konusu iyi öğrenildiği takdirde daha uzun, daha güzel, daha sanatsal cümleler kurulabileceği, gereksiz sözcük tekrarları yapılmayacağ 1 gibi. Üzerinde durulan her konu, nitelikli başka metinler üzerinde yürütülen ek çalışmalarla pekiştirilmelidir. Bu sürecin her basamağında öğretmen, kurallara öğrencinin ulaşmasını să̆layacak çalışmalar yaptırmalı, onu konunun önemine ve gerekliliğine ikna etmeli, onlara bu konuyu öğrenmenin anlama ve anlatma becerilerine ne gibi katkılar sağlayacă̆ını açıklamalıdır. Dil bilgisi ve onun bir alt alanı olan cümle bilgisi öğretimi; yaratıcı, düşündürücü, dönüştürücü ve üretken olmalıdır. Bilginin günlük yaşamında ne işe yarayacağı, ona neler sağlayacağı, çocuğun bilmesi gereken bir konudur. Yığma bilgileri, edilgin biçimde dinleyen çocuğa aktarmanın çocuğun özerk birey olmasına hiçbir katkısı yoktur (Aslan, 2017, s. 30- 33).

Güneş tarafından belirtildiğine göre dünyada çoğu ülkede dil öğretiminde yapılandırmacı yaklaşım uygulanmaktadır. Bu yaklaşım gereği dil bilgisi öğretiminde yeni dil bilgisi, beceri ve etkinlik yaklaşımı, tümevarım modeli ve sezdirme yöntemi kullanılmaktadır. Dil bilgisi; ayrı bir ders olarak değil, dil öğrenme alanlarının içinde ele alınmaktadır. Sezdirme yöntemiyle dilin soyut kurallarını ezberlemeye değil, öğrencinin dil ve zihinsel becerilerini geliştirmeye ağırlık verilmekte; dil kurallarını bilimsel bilgiler gibi çeşitli deneysel etkinliklerle keşfederek öğrenmeleri amaçlanmakta; dilin işlev ve kuralları ile mantığını iyi öğrenerek bunları okuma ve yazma çalışmalarında kullanmaları öngörülmektedir. Sezdirme yöntemiyle dil bilgisi öğretimi; sunuş, olayı gözleme, kural ve hipotez oluşturma, alıştırma yapma ve uygulamaya aktarma olmak üzere altı aşamada gerçekleştirilmektedir (Güneş, 2013, s. 171):

Sunuş basamağında öğretmen; öğrenciler ile birlikte dil bilgisi olaylarını çeşitli sorularla incelemekte, olayla ilgili yazım ve düzeltmeler yapmakta ve yaptırmakta, anlama sorunlarını tartışarak öğrencilerin dil bilgisinin önemini anlamalarını sağlamakta, ele alınan dil bilgisi olayıyla ilgili öğrencilerin ön bilgilerini harekete geçirmektedir (Güneş, 2013, s. 180, 183).

Olayı gözlemleme basamağında öğrencileri okudukları metinlerdeki dil bilgisi kavramını tanımaya ve olayları gözlemlemeye davet eder (Güneş, 2013, s. 180, 183).

Örnekleri değiştirme ve hipotez oluşturma basamağında öğrencilerden kendi ölçütlerine göre sınıflama yapmalarını ister, onların kullandıkları süreçleri gözlemler ve not eder, onları olayın işlevleri hakkında hipotezler oluşturmaya davet eder, oluşturulan hipotezleri öğrencilerle tartışır, ihtiyaca göre gerekli dil bilgisi değişimlerini açıklayıcı biçimde öğretir (Güneş, 2013, s. 181, 183).

Hipotezleri doğrulama basamağında öğrencileri hipotezlerinin başka metinlerde uygulanabilirliğini doğrulamak için uygun dil değiş̧imlerini kullanmaya davet eder (Güneş, 2013, s. $181,183)$. 
Kural oluşturma basamağında öğrencilerden kesin kurallar oluşturmalarını, onları kaynak dil bilgisi kitaplarında inceleme ve değerlendirme yapmalarını ister (Güneş, 2013, s. $181,183)$.

Alıştırma yapma basamağında etkinlikler planlar ve öğrencilerin yeni bilgileri öğrenmeleri için bu etkinlikleri onlara verir (Güneş, 2013, s. 182- 183).

Uygulamaya aktarma basamağında ise metin yazım sürecinde öğrenilenleri geliştirmek için olayı kontrol eder (Güneş, 2013, s. 182- 183).

Tüm bu söylenilenler bir arada değerlendirildiğinde bu çalışmada incelenen 8. Sinıf Türkçe Ders, Öğrenci Çalışma ve Öğretmen Kllavuz Kitabı'nda (MEB; 2017a, 2017b, 2017c) yer alan cümle bilgisi etkinliklerinin cümle bilgisi alanına dâhil edilebilecek konu kapsamı açısından geniş yelpazeye yayılmış bir çeşitlilik sergilediği, ancak gelecekte hazırlanacak kitapların başta Göğüş (1978), Sağır ve Demir Atalay (2016) ve Aslan (2017) tarafindan ortaya konulan görüşler ile özellikle Güneş (2013) tarafından basamakları hakkında etraflıca bilgi verilen sezdirme yöntemi ile dil bilgisi öğretimi sürecinin altı temel basamağı dikkate alınarak düzenlenecek etkinliklerle güncellenmesi ve zenginleştirilmesi önerilebilir.

\section{Kaynakça}

Arhan, S., Başar, S., Demirel, T. (2017a). İlköğretim türkçe 8 ders kitabı. Ankara: MEB Yayınları.

Arhan, S., Başar, S., Demirel, T. (2017b). İlköğretim türkçe 8 öğrenci çalışma kitabı. Ankara: MEB Yayınları.

Arhan, S., Başar, S., Demirel, T. (2017c). Illköğretim türkçe 8 öğretmen kılavuz kitabı. Ankara: MEB Yayınları.

Aslan, C. (2017). Örnek eğitim durumlarıyla türkçe- türk dili ve edebiyatı öğretimi. Ankara: Anı Yayınc1lik.

Atabay, N., Özel, S., Çam, A. (1981). Türkiye türkçesinin sözdizimi. Ankara: Türk Dil Kurumu Yayınları.

Büyüköztürk, Ş., Akgün, E. A., Karadeniz, Ş., Demirel, F., Kılıç Çakmak, E. (2010). Bilimsel araştırma yöntemleri. Ankara: Pegem Akademi Yayınları.

Çepni, S. (2009). Araştırma ve proje çalışmalarına giriş. 4. Bask1. Trabzon: Erol Ofset.

Ercilasun, A. B. (2010). "Türkçede genel anlatım bozuklukları", Türk Dili ve Kompozisyon Kitabı içinde, (Korkmaz, Z.; Ercilasun, A. B.; Gülensoy, T.; Parlatır, İ.; Zülfikar, H.; Birinci, N.). (4. Baskı). Bursa: Ekin Basım Yayın Dağıtım.

Ergin, M. (2013). Türk dil bilgisi. İstanbul: Bayrak Yayınları.

Göğüş, B. (1978). Orta dereceli okullarımızda türkçe ve yazın eğitimi. Ankara: Gül Yayınevi.

Güneş, F. (2013). "Yapılandırmacı yaklaşımla dil bilgisi öğretimi”. Eğitimde Kuram ve Uygulama Journal of Theory and Practice in Education, 9(3), ss. 171- 187.

Karaağaç, G. (2009). Türkçenin söz dizimi. (1. Baskı). İstanbul: Kesit Yayınları.

Karahan, L. (2018). Türkçede söz dizimi. (25. Baskı). Ankara: Akçağ Yayınları.

Karasar, N. (1994). Bilimsel araştırma yöntemi. Ankara: 3A Araştırma Eğitim Danışmanlık Ltd.

Korkmaz, Z. (2014). Türkiye türkçesi grameri/ şekil bilgisi. (4. Bask1). Ankara: Türk Dil Kurumu Yayınları.

www.turkishstudies.net/social 
Korkmaz, Z. (1992). Gramer terimleri sözlüğü. Ankara: Türk Dil Kurumu Yayınları.

MEB, (2017). Türkçe dersi ögretim programı (ilkokul ve ortaokul 1, 2, 3, 4, 5, 6, 7 ve 8. sinfflar). Ankara: MEB Yayınları.

MEB, (2019). Türkçe dersi ögretim programı (ilkokul ve ortaokul 1, 2, 3, 4, 5, 6, 7 ve 8. sinıflar). Ankara: MEB Yayınlar1.

Özmen, M. (2013). Türkçenin sözdizimi. (1. Bask1). Adana: Karahan Kitabevi.

Sağır, M., Demir Atalay, T. (2016). Yeni programa uygun etkinliklerle dil bilgisi ögrretimi. Ankara: Pegem Akademi Yayınları. 